(C) 2020 Elsevier B.V. All rights reserved. Access to this work was provided by the University of Maryland, Baltimore County (UMBC)

ScholarWorks@UMBC digital repository on the Maryland Shared Open Access (MD-SOAR) platform.

Please provide feedback

Please support the ScholarWorks@UMBC repository

by emailing scholarworks-group@umbc.edu and

telling us

what having access to this work means to you and why

it's important to you. Thank you. 


\section{Working PaperSeries}

\section{Loan Loss Reserves, Accounting Constraints, and Bank Ownership Structure}

WP 11-09

Eliana Balla

Federal Reserve Bank of Richmond

Morgan J. Rose

University of Maryland, Baltimore County 


\title{
Loan Loss Reserves, Accounting Constraints, and Bank Ownership Structure
}

This version: November 17, 2011

\author{
Eliana Balla ${ }^{1}$ \\ Federal Reserve Bank of Richmond \\ Morgan J. Rose \\ University of Maryland, Baltimore County
}

Working Paper No. 11-09

\begin{abstract}
This paper examines how the tightening of accounting constraints associated with the SunTrust bank decision in 1998 impacted the loan loss reserve policies of banks differently based on ownership structure. The SunTrust case, the result of an SEC inquiry over possible overstating of loan loss reserves, represented a strengthening of accounting priorities, which stress the importance of the reserve account for financial statement objectivity and comparability, relative to supervisory priorities, which emphasize the role of reserves for bank solvency through changing economic environments. The evidence presented indicates that publicly held banks, which fall directly under the SECs purview, reduced their loan loss reserve and provisions relative to privately held banks. Evidence also indicates that the positive relationship between bank earnings and provisions weakened, consistent with a reduction in either earnings management or early recognition of losses.
\end{abstract}

JEL classification: G21; G28; G32; E65

Keywords: Loan loss provisioning; Earnings management; Income smoothing; Ownership structure; Financial institutions; Banking regulation.

\footnotetext{
${ }^{1}$ We thank seminar participants at the Federal Reserve Bank of Richmond and participants at the Federal Reserve System Committee on Financial Structure and Regulation conference for comments and Susan Maxey for excellent research assistance. Please contact Eliana Balla at Eliana.Balla@,rich.frb.org with any comments. The views expressed belong to the authors and do not represent the views of the Federal Reserve Bank of Richmond or the Federal Reserve System.
} 


\section{Section I - Introduction}

A bank"es loan loss reserve (LLR) account, also known as the allowance for loans and leases losses (ALLL), is a contra-asset account used to reduce the value of total loans and leases on the bank"s balance sheet by the amount of losses that bank managers anticipate in the most likely future state of the world. ${ }^{2}$ Provisioning is the act of building the LLR account through a provision expense item on the income statement. ${ }^{3}$ As a relatively large accrual for commercial banks, loan loss provisions have a significant effect on earnings and regulatory capital. ${ }^{4}$ With respect to LLR policy, there is a tension between what might be termed accounting priorities and supervisory priorities. ${ }^{5}$ Accounting priorities emphasize the objectivity and comparability of financial statements to facilitate bank monitoring. As reflected under accounting standards set by the Financial Accounting Standards Board (FASB) ${ }^{6}$, an inherent credit loss should be recognized only upon the occurrence of an event indicating that a loss is probable and if the amount of the loss can be reasonably estimated. ${ }^{7}$ Supervisory priorities emphasize the ability of banks to maintain solvency through changing business environments. The evaluation of the adequacy of LLR is one of the most important functions of bank examinations. ${ }^{8}$ From the perspective of bank supervisors, an adequate LLR is a safety and soundness issue because a deficit in LLR implies that the bank"es capital ratios overstate its ability to absorb unexpected

\footnotetext{
${ }^{2}$ Economists generally view LLR as intended to capture expected future losses that will occur if a borrower does not repay in accordance with the loan contract, a view most helpful for the pricing of loans in the secondary market. Benston and Wall (2005) point out that if loans could be reported reliably at fair value, where fair value is value in use, there would be no need for a loan loss provision or reserves. A market for the full transfer of credit risk does not exist and loans cannot be reported reliably at fair value.

${ }^{3}$ During 1992-2010, the median and mean ratios of loan loss provisions to earnings before provisions and taxes for all U.S commercial banks (winsorized at the $1^{\text {st }}$ and $99^{\text {th }}$ percentiles) were 6.7 and 13.0 percent, respectively. During 2007-2010, those ratios were 9.4 and 22.5 percent.

${ }^{4}$ See Ahmed et al. (1999).

${ }^{5}$ See Wall and Koch (2000) for an extensive summary of the theoretical and empirical evidence on bank loan loss accounting and LLR philosophies.

${ }^{6}$ Financial Accounting Standards Board and the International Accounting Standards Board. Information for Observers. March 2009 Meeting. Project: Loan Loss Provisioning.

${ }^{7}$ Section II of this paper discusses regulatory and accounting standards concerning LLR policy in greater detail.

${ }^{8}$ See Gunther and Moore (2003a and b) for a discussion of the role of bank exams for bank LLR.
} 
losses. ${ }^{9}$ For the supervisory priorities to hold in practice, bank managers must incorporate into their loan loss provisioning expectations about future losses due to changes in economic conditions that affect credit defaults for loan losses, even if no event has yet occurred to indicate specific estimable losses..$^{10}$ The tension between objective but backward-looking historical data on the one hand and subjective but forward-looking expectations on the other reflects a trade-off between two laudable goals, transparency and safety and soundness.

The "incurred loss model" reflected in current LLR policy has been criticized in the context of the recent financial crisis as contributing to the procyclicality of LLR. As with bank regulatory capital more broadly, the concern is that with a reserving approach in which banks have to rapidly raise reserves during bad times, the bad times could become prolonged. Laeven and Majnoni (2003) and Bouvatier and Lepetit (2008) discuss the procyclicality of loan loss provisions with cross-country data. They argue that banks delay provisioning for bad loans until economic downturns have already begun, amplifying the impact of the economic cycle on banks ${ }^{\text {ee }}$ income and capital.

If loan losses are not recognized until the occurrence of specific events, then during good economic times when fewer such events occur, LLR will be relatively low. An event-driven approach to LLR also does not reflect the relaxation of underwriting standards and greater risktaking that often occurs in banks during a booming economy, given that most of the resulting bad loans will only reveal themselves in a recession. ${ }^{11}$ Once adverse economic conditions arise and

\footnotetext{
${ }^{9}$ The view that loan loss reserves serve to cover expected credit losses and capital unexpected losses is reflected in the Basel II (2006) and Basel III(2011) capital frameworks. See Laeven and Majnoni (2003), Appendix A for a detailed description of the conceptual relationship between loan loss reserves, provisions, capital, and earnings.

${ }^{10}$ One way to separate the current accounting perspective from an expected loss perspective is by stating that no expected economic impacts are taken into account in current LLR methodology. A bank manager cannot, for example, consider the increases in default risk due to future increases in unemployment.

${ }^{11}$ Independent of any LLR effects, stylized facts and a burgeoning literature suggest that bank lending behavior is highly procyclical. Many explanations have been presented. The classical principal-agent problem between shareholders and managers may lead to procyclical banking if managerse objectives are related to credit growth.
} 
more credit impairment and default events occur, banks must quickly increase their provisioning to raise their LLR. Requiring banks to build up reserves during an economic downturn, when bank funds may already be otherwise strained, can compel banks to reduce lending activities, potentially magnifying the downturn by exacerbating a credit crunch. A less procyclical LLR policy, in which banks are able to build a buffer of loan loss reserves during boom times, could position banks to better weather bust times, but accounting guidelines pose a constraint. Many banks entered the financial crisis of 2007-2009 with low loan loss reserves, then had to sharply increase provisions in recognition of pending losses, which for many banks more than offset earnings and reduced capital. (See Figure 1.) In this manner, the banking sector may have magnified the cycle.

In a speech in March 2009, Ben Bernanke, the chairman of the Board of Governors of the Federal Reserve, stated that there is "considerable uncertainty regarding the appropriate levels of loan loss reserves over the cycle. As a result, further review of accounting standards governing...loan loss provisioning would be useful, and might result in modifications to the accounting rules that reduce their procyclical effects without compromising the goals of disclosure and transparency."12 In the aftermath of the 2007-2009 experience, the Basel Committee on Banking Supervision formally encouraged accounting regulatory bodies to pursue a forward looking loan loss provisioning regime in the Basel III (2011) framework. ${ }^{13}$ As of the

\footnotetext{
Rajan (1994) suggests that credit mistakes are judged more leniently if they are common to the whole industry. Berger and Udell (2003) suggest that, as the time between the current period and the last crisis increases, experienced loan officers retire or genuinely forget about the lending errors of the last crisis and become more likely to make "bad" loans. LLR effects may exacerbate this otherwise present procyclicality of bank lending.

${ }^{12}$ Bernanke, Ben. Financial Reforms to Address Systemic Risk. Remarks at the Council on Foreign Relations. Washington, D.C. March 10, 2009.

${ }^{13}$ While Basel III (2011) explicitly builds in countercyclical capital requirements, no countercyclical provisioning requirements are specified. Spain"s experience with the use of loan loss provisions as a macroprudential tool garnered attention in the policy debates of 2007-2009. See Balla and McKenna (2009) for a discussion of the differences between the U.S. incurred loss approach and Spain"s dynamic provisioning approach.
} 
time of this writing, FASB is reconsidering its policy to potentially allow for more forwardlooking loan loss provisions. ${ }^{14}$

This paper contributes to the renewed interest in LLR policies by presenting evidence on bank-level changes in LLR account levels and provisioning in response to a shift in the regulatory environment. Specifically, the 1998 SunTrust decision (described below) by the Securities and Exchange Commission (SEC) indicated stricter enforcement of accounting priorities relative to supervisory priorities in LLR policy, but directly affected only publicly held banks that fall under the SEC ${ }^{\text {ees }}$ purview. By exploiting both temporal variation in regulatory emphasis and cross-sectional variation in bank ownership structure, we can identify the effect of the strengthening of the accounting constraint on LLR and provisioning.

Increasing reserves when earnings are high could reflect bank managers building up reserves as a precaution against economic downturns as supervisory priorities suggest. It could also reflect managing earnings (or "smoothing income") across the business cycle to portray greater earnings stability than is really the case, which is viewed as undesirable by the accounting profession. Wall and Koch (2000) offer a review of the theoretical and empirical evidence on earnings management via loan loss accounting. The evidence they summarize suggests that banks have an incentive to manage reported earnings and that, while the empirical evidence is not conclusive, several papers find that banks use loan loss accounting to manage reported earnings. ${ }^{15}$

\footnotetext{
${ }^{14}$ Financial Accounting Standards Board. May 26, 2010. Proposed Accounting Standards Update- - Accounting for Financial Instruments and Revisions to the Accounting for Derivative Instruments and Hedging Activities"

${ }^{15}$ Also see Greenwald and Sinkey (1988) and Wahlen (1994).
} 
The existing literature has typically focused on publicly held banks. ${ }^{16}$ In publicly held firms, managers may have incentives to manage earnings to maximize compensation tied to meeting specific earnings thresholds. In addition, earnings reports provide signals to investors and analysts and managing earnings allows managers to control the signals. It is unclear whether privately held firms manage earnings more or less than publicly held firms. Because outside investors have relatively less information on privately held firms, reported earnings from privately held firms may have relatively more importance in terms of signaling, possibly giving privately held firms greater incentives to manage earnings than publicly held firms. ${ }^{17}$ On the other hand, assuming that equity-based compensation is less relevant for privately held firms, managers at privately held firms will have less incentive to manage earnings in order to influence equity value. Beatty et al. (2002) find that both public and private banks manage earnings, but public banks manage earnings more. ${ }^{18}$ Fonseca and González (2008) provide a panel study of 40 countries (excluding the United States) and find that neither the amount of income smoothing using loan loss provisions nor the difference in income smoothing using loan loss provisions between public and private banks is stable across countries. ${ }^{19}$

\section{Section II - Background on Loan Loss Reserves}

Bankers desire flexibility in determining appropriate reserves in recognition of subjective assessments of future losses. Bank regulators desire flexibility in recognition of the importance

\footnotetext{
${ }^{16}$ See Kwan (2004) for a general discussion of differences in performance and risk taking behavior of publicly traded vs. privately held U.S. bank holding companies.

${ }^{17}$ See Adams (2009) on earnings management with respect to thrift IPOs.

${ }^{18}$ Beatty et al. (2002) define "managed earnings" as more frequent announcements of small increases in earnings than small decreases, reflecting managers" incentives to avoid the reporting of negative earnings when possible. Accounting researchers define different aspects of the use of discretion in bank accounting. For another example in differences between publicly held and privately owned banks see Nichols et al. (2009).

${ }^{19}$ None of the above studies use samples that extend past 2002, while our sample includes the years leading up to the financial crisis of 2007-2009.
} 
of LLR for bank safety and soundness. Accounting standard setters stress the need for transparency and comparability across bankse financial statements. In this section, we describe the accounting and bank regulation policies for LLR, both in terms of specific characteristics and the history behind these policies.

Provisioning for loan losses in the United States is accounted for under FAS Statement 5, Accounting for Contingencies (issued in March 1973), and FAS 114, Accounting by Creditors for Impairment of a Loan - an amendment of FASB Statements 5 and 15 (issued in May 1993). Impaired loans evaluated under FAS 114, which provides guidance on estimating losses on loans evaluated individually, must be valued based on the present value of cash flows discounted at the loan"s effective interest rate, the loan "es observable market price, or the fair value of the loan $\mathrm{s}$ collateral if they are collateral dependent. Loans individually evaluated under FAS 114 that are not found to be impaired are transferred to homogenous groups of loans that share common risk characteristics, which are evaluated under standard FAS 5. FAS 5 provides for accrual of losses by a charge to the income statement based on estimated losses if two conditions are met:

(1) information available prior to the issuance of the financial statements indicates that it is probable that an asset has been impaired or a liability has been incurred at the date of the financial statement, and

(2) the amount of the loss can be reasonably estimated. ${ }^{20}$

Both FAS 114 and 5 allow banks to include environmental or qualitative factors in consideration of loan impairment analysis. Examples of these factors include, but are not limited to, underwriting standards, credit concentration, staff experience, local and national economic business conditions. In addition, FAS 5 allows for the use of loss history in impairment

${ }^{20}$ Financial Accounting Standards Board, Summary of Statement No. 5: Accounting for Contingencies, March 1973. 
analysis. ${ }^{21}$ These elements provide bankers with flexibility in determining the level of provisions taken against incurred losses when they are well substantiated by relevant data or documentation required by supervisors and accountants. Banks identify losses by categorizing loans based on their payment status (i.e. current, 30 days past due, 60 days past due, etc.) and the severity of delinquency (which can vary by asset class) and assess whether a provision should be taken on loans they expect to experience a loss, if the loss is probable and estimable. ${ }^{22}$

The Basel Accord of 1988 set current rules for bank capital regulation and the role of LLR in capital regulation. In 1991, FDICIA enacted these changes into law. LLR were no longer counted as a component of Tier 1 capital but were counted toward Tier 2 capital, up to 1.25 percent of the bank"es risk-weighted assets. So if a bank increases its LLR, the effect is to increase Tier 2 capital while reducing retained earnings and Tier 1 capital. ${ }^{23}$ If, as a result of this transfer, Tier 1 regulatory thresholds become binding, (usually in bad economic times), bank supervisors would require the bank to issue more capital or reduce its measured risk. Laeven and Majnoni (2003) have argued that since 1991 “...from the perspective of compliance with regulatory capital requirements, it became much more effective for U.S. banks to allocate income to retained earnings (entirely included in Tier 1 capital) than to loan loss reserves (only partially included in Tier 2 capital).".24

The SEC's ruling on the earnings restatement for SunTrust bank in 1998 reflected increased concerns at this organization that publicly traded U.S. bank holding companies were using loan loss provisions to manage reported earnings. The SEC and bank regulators entered a

\footnotetext{
${ }^{21}$ SR 06-17: Interagency Policy Statement on the ALLL, December 13, 2006. SR 01-17: Policy Statement on ALLL Methodologies and Documentation for Banks and Savings Institutions, July 2, 2001. SR 99-22: Joint Interagency Letter on the Loan Loss Allowance, July 26, 1999.

${ }^{22}$ See Walter (1991) for an explanation of how banks identify and categorize defaults.

${ }^{23}$ Ahmed et al. (1999) provide evidence that, in line with reduced incentives in the new regulatory regime of risk based capital, banks engaged in less capital management through loan loss provisions in 1991-1995 compared to 1985-1990.

${ }^{24}$ Laeven and Majnoni (2003), p. 194.
} 
period of dialogue reflected in interagency letters to banks in November 1998, March 1999, and July $1999 .{ }^{25}$ The stance of the interagency communications is one of "prudent, conservative, but not excessive" LLR.

Throughout the sample period we study, banking regulators have remained concerned with the role that loan losses and banksee reserves for losses play in insolvency risk. Banking regulator comments following the SunTrust ruling continued to emphasize the importance of building a LLR cushion during good economic times. Former Comptroller of the Currency John Dugan reiterated that same point in 2009 stating that ...banking supervisors love the loan loss reserve. When used as intended, it allows banks to recognize an estimated loss on a loan or portfolio of loans when the loss becomes likely, well before the amount of the loss can be determined with precision and is actually charged off. That means banks can be realistic about recognizing and dealing with credit problems early, when times are good, by building up a large ,war chest“ of loan loss reserves. Later, when the loan losses crystallize, the fortified reserve can absorb the losses without impairing capital, keeping the bank safe, sound, and able to continue extending credit. ${ }^{26}$

But accounting guidelines, as enforced subsequent to the SunTrust decision, may have limited the ability of loan loss reserves to function in the way summarized by Comptroller Dugan.

\section{Section III - Hypotheses}

\footnotetext{
${ }^{25}$ The full text of these interagency letters can be found at http://www.federalreserve.gov/bankinforeg/srletters/srletters.htm

${ }^{26}$ Dugan, John. Loan Loss Provisioning and Procyclicality. Remarks before the Institute of International Bankers. March 2, 2009.
} 
Based on the preceding discussion, in this paper we empirically test the following hypotheses:

Hypothesis 1a: Following the SunTrust decision, the level of loan loss reserves of publicly held banks declined relative to that of privately held banks.

Hypothesis 1b: The level of loan loss reserves of privately held banks was unaffected by the SunTrust decision.

By requiring a stricter adherence to accounting rules on the part of banks subject to SEC oversight, the SunTrust decision constrained the ability of publicly held banks to use loan loss management during times of positive earnings to either smooth income or prudentially increase loan loss reserves as a precaution against future downturns. Privately held banks are not subject to SEC oversight, and so their loan loss management need not have been affected. However, if bank supervisors incorporated the requirements of the SunTrust decision into the rules applicable to all banks, then privately held banks may also have been forced to reduce their levels of reserves following the decision. Hypothesis 1a implies that the SunTrust decision placed more binding constraints on publicly held banks than on privately held banks, but allows for constraints of at least some degree on privately held banks. Hypothesis $1 \mathrm{~b}$ implies that the SunTrust decision did not impose binding constraints on privately held banks.

Hypothesis 2a: Following the SunTrust decision, provisioning for loan losses by publicly held banks declined relative to that of privately held banks.

Hypothesis 2b: Provisioning for loan losses of privately held banks was unaffected by the SunTrust decision.

Hypotheses $2 \mathrm{a}$ and $2 \mathrm{~b}$ are based on the same rationale as Hypotheses $1 \mathrm{a}$ and $1 \mathrm{~b}$, only applied to bankse" provisions for loan losses rather than their overall levels of loan loss reserves. 
Hypothesis 3a: Following the SunTrust decision, the relationship between pre-provision earnings and loan loss provisions for publicly held banks weakened relative to that for privately held banks.

Hypothesis 3b: The relationship between pre-provision earnings and loan loss provisions for privately held banks was unaffected by the SunTrust decision.

If banks increase loan loss provisioning when earnings are high, as a means to either maximize executive compensation or increase loan loss reserves as a buffer against future loan losses, our empirical analysis should find a positive relationship between pre-provision earnings and loan loss provisions. If the stricter adherence to accounting rules associated with the SunTrust decision constrained the ability of banks to engage in such loan loss management, then that positive relationship will be weaker following the decision. Publicly held banks are directly subject to SEC oversight, suggesting that the relationship between earning and provisions should weaken more dramatically for publicly held banks than for privately held banks, as stated in Hypothesis 3a. Hypothesis $3 \mathrm{~b}$ implies that the SunTrust decision did not impose binding constraints on the ability of privately held banks to manage earnings via loan loss accounting.

Note that based on the discussion in the previous sections, there is reason to think that the relationship between earnings and provisions should weaken more for privately held banks than for publicly held banks, in contradiction to Hypotheses $3 \mathrm{a}$ and $3 \mathrm{~b}$. If prior to the SunTrust decision privately held banks had greater incentives to engage in loan loss management due to their greater asymmetric information, and if bank supervisors incorporated the requirements of the SunTrust decision into the rules applicable to all banks, then the constraints imposed after the SunTrust decision would be more binding for privately held banks than for publicly held banks. Stated differently, if prior to the SunTrust decision SEC oversight and market analyst coverage 
already constrained publicly held banks from loan loss management, then the additional constraints that followed the SunTrust decision would primarily affect the behavior of privately held banks.

\section{Section IV- Data and Methodology}

The data for this paper come primarily from banking regulatory databases. Our first task was to identify publicly traded banking institutions. Using a mapping maintained by the Federal Reserve Bank of New York (the mapping is valid from January 1990 to December 2007), we identify supervised banking institutions that are listed on the NYSE, AMEX, or NASDAQ. ${ }^{27}$ Because we are interested in all banking companies that file with the SEC, and not just the ones traded in the three largest exchanges, we use SNL Financial to identify additional publicly traded banking institutions.

While equity offerings are made at the holding company level, reserving policies are generally set at the bank level. Both because managerial decisions on LLR are made at the bank level and for data completeness (small bank holding companies report less frequently and not on a consolidated basis), we use bank-level financial data from regulatory filings (Call Reports). We obtain structure data on relationships between holding companies and banks, as well as data on firm age, bank mergers and acquisitions, and failures, from Federal Reserve databases. If the bank holding company or the top holding company (one layer removed from the bank) were traded publicly, we consider the bank publicly held.

Our sample period begins in the first quarter of 1992, when the current rules for how loan loss reserves enter into bank capital first went into effect, and ends in the second quarter of

\footnotetext{
${ }^{27}$ The mapping is available at http://www.newyorkfed.org/research/banking_research/datasets.html.
} 
2007. ${ }^{28}$ Both loan loss reserves and provisions increased dramatically during the recent financial crisis (see Figure 1), which could skew our results if included in the sample. From this initial sample, we drop banks located outside of the continental United States and banks that are not active lenders, which we define as banks for which total loans never exceeds 5 percent of total assets. We remove outliers by dropping observations for which the value of any of the ratio variables defined below is beyond four standard deviations from that variable"s mean value. ${ }^{29}$ Taken together, these sample criteria eliminate approximately 1.4 percent of the original observations. The final dataset includes over 500,000 bank-quarter observations from 13,317 banks. As consolidation in the banking industry progressed through our sample period, the number of banks declined from 11,400 in 1992 to 6,889 in 2007. Approximately 73 percent of our sample banks are privately held throughout the sample period and 16 percent are publicly held throughout the sample period. The remainder switch ownership structure, with the vast majority switching from private to public.

Table 1 presents summary statistics for the variables used in the empirical analysis. The dependent variables are loan loss reserves $(L L R)$ and provisions for loan losses $(P L L)$. Two of the key explanatory variables for testing our hypotheses are an indicator equaling one in quarters following the SunTrust decision (AfterST) and an indicator equaling one for publicly traded banks or banks owned by publicly traded holding companies (Public). As the mean value of 0.49 shows, AfterST splits the dataset into almost equally sized subsamples. The percentage of banks that were publicly held at the start of our sample was 18 percent, reached a high of 20 percent in 1994, and then declined steadily to a low of 11 percent in 2007. Figure 2 provides

\footnotetext{
${ }^{28}$ Both the tax and capital regulatory regimes are constant throughout this sample. The last change to tax treatment for loan loss provisions occurred in 1986. Note that some financial data from 1990 and 1991 are used to construct lagged variables.

${ }^{29}$ See Holod and Peek (2007).
} 
greater detail on the distribution of Public over our sample, for all sample banks and for banks divided by size at $\$ 1$ billion and $\$ 10$ billion in total assets.

Other explanatory variables include controls for bank balance sheet and income statement variables relevant to loan losses, as well as controls for broader bank characteristics and macroeconomic activity. Non-performing loans $(N P T L)^{30}$ is a proxy for poor asset quality, and is expected to be positively associated with $L L R$ and $P L L$. The change in total loans ( $\triangle$ Loans) could be negatively associated with $L L R$ and $P L L$ if loan growth indicates an expansion of profitable investment opportunities due to expected economic growth, or it could be positively associated with $L L R$ and $P L L$ if loan growth indicates deteriorating underwriting quality. ${ }^{31} \mathrm{~A}$ positive relationship between earnings before provisioning $(E B P)$ and $P L L$ would indicate that banks on average increase their loan loss provisioning and reserves when earnings are higher, consistent with both income smoothing and precautionary loan loss management. Shareholder equity ( $E Q)$ captures firm capital structure, and could be positively or negatively related to $L L R$ depending on whether capital management is a complement or a substitute for loan loss management. $E Q$ should be negatively related to $P L L$ as provisions directly influence total equity by reducing net income. Balance sheet variables (LLR, NPTL, $\triangle$ Loans, and $E Q)$ are expressed as percentages of total assets from the previous quarter. Income statement variables $(P L L$ and $E B P)$ are expressed as percentages of average assets from the previous quarter. Average net charge-offs as a percentage of average assets over the previous eight quarters $(N C O)$ reflects bank use of historical loan losses in assessing future loan losses, and it is expected to be positively associated with $L L R$ and $P L L$.

\footnotetext{
${ }^{30}$ Non-performing loans refers to the sum of loans $90+$ days past due and those in a nonaccrual status.

${ }^{31}$ See Keeton (1999) and Foos et al. (2010).
} 
Bank size (Size) is measured as the natural log of bank total assets (in thousands) from the previous quarter. The percentage change in real GDP over the previous quarter $(\triangle G D P)$, obtained from the Federal Reserve Bank of Saint Louis, proxies for economic growth. Three indicator variables capture events in the life cycle of a bank that may be associated with atypical loan loss reserves and provisioning. DeNovo equals one in the first five years of a banke's life. Fail equals one in the final quarter of a bank"s existence and the previous three quarters. Merger equals one if the bank merged with another firm during the current quarter. All specifications also include quarter indicator variables to control for seasonality, a quadratic time trend, and a constant term.

To conduct the empirical analysis we use panel estimation with random effects at the bank level. Laeven and Majnoni (2003) and Fonseca and González (2008) both use the GMM estimation technique developed by Arellano and Bond (1991) to examine dynamic models of loan loss provisioning, but the large number of instruments required combined with the size of our dataset (two orders of magnitude greater than those authors"e datasets) makes that technique computationally intractable here. Laeven and Majnoni (2003) present results from both panel estimation with random effects and Arellano-Bond estimation, with similar results across the two models. ${ }^{32}$ They also find evidence of second-order correlation in the first-differenced errors for their U.S. bank sample, suggesting that Arellano-Bond estimates for that sample may be biased. Due to computing constraints we were unable to employ Arellano-Bond estimation for our full dataset, but when we did for randomly selected subsets of our dataset we also consistently found evidence of second-order correlation. For comparability with the previous literature we use

\footnotetext{
${ }^{32}$ Specifically, in their pooled international sample, all of their explanatory variables have the same signs and levels of significance across the two models. In their sample of U.S. banks only, their coefficient estimate for loan growth changes sign across models, but all other explanatory variables retain their signs and levels of significance. Our sample contains only U.S. banks.
} 
panel estimation with random effects rather than fixed effects. As discussed in the next section, in unreported work we repeated all of our analyses using fixed effects and find similar results throughout.

\section{Section V - Empirical Analysis}

Section V.1 - Univariate Analysis

Table 2 presents results of univariate analyses of the means of $L L R$ (Panel A) and PLL (Panel B) for publicly held and privately held banks before and after the SunTrust decision. The first row of Panel A shows that prior to the SunTrust decision, the level of loan loss reserves for publicly held banks was on average 0.192 percent of assets higher than the level for privately held banks. That difference in means is statistically significant, and is economically substantial given the overall sample mean $L L R$ of 0.933 percent of assets. Hypothesis 1a predicts that this difference should decrease following the SunTrust decision, and that prediction is borne out in the second row. The post-SunTrust difference in means is less than half the size of pre-SunTrust difference, and the magnitude of the drop is more than 30 times the standard error of either difference. Hypothesis $1 \mathrm{~b}$ predicts that mean $L L R$ for privately held banks should be the same before and after the SunTrust decision, but the second column of Panel B indicates a significant decline in mean $L L R$ across periods.

Panel B of Table 2 shows the same analysis for PLL, with similar results. The difference in means in the first row is 0.093 percent of assets, quite substantial relative to the overall sample mean PLL of 0.215. The difference in means in the second row of Panel B is smaller than that in the first row, with the magnitude of the drop being about seven times greater than either standard error. This is consistent with Hypothesis 2a. The second column of Panel B indicates that mean 
$P L L$ for privately held banks increased following the SunTrust decision, which is inconsistent with Hypothesis $2 \mathrm{~b}$ and with our larger supposition that if the SunTrust decision had any effect on the provisioning of privately held banks it should have decreased mean PLL. This inconsistency with expectations emphasizes the need for multivariate analysis.

\section{Section V.2 - Multivariate Analysis}

Table 3 presents results from panel estimations using $L L R$ as the dependent variable. The key variables of interest are Public, AfterST, and their interaction. Models 1 and 2 employ sample periods before and after the SunTrust decision, respectively. Hypothesis 1 predicts that the coefficient estimate for Public is smaller in the post-SunTrust period than in the pre-SunTrust period. The coefficient estimate for Public in model 1 indicates that prior to the SunTrust decision the level of loan loss reserves of publicly held banks was greater than that of privately held banks by 0.136 percent of assets. This is an economically substantial difference across ownership structures, equal to 16 percent of the sample median $\operatorname{LRR}(0.136 / 0.848)$. In model 2 , the coefficient estimate drops nearly in half to 0.072 percent of assets ( 8.5 percent of the sample median), consistent with Hypothesis 1a. The signs of the estimates for the other explanatory variables here and in subsequent tables are consistent with expectations. The positive coefficients for $\Delta$ Loans suggest that loan growth is associated with declining credit quality.

Models 3 and 4 separate the sample into publicly held and privately held banks. The coefficient estimates for AfterST indicate that both publicly held and privately held banks on average had lower levels of loan loss reserves in the period following the SunTrust decision. The point estimate for publicly held banks is twice as large (in absolute value) as the one for 
privately held banks, consistent with Hypothesis 1a, while the negative and significant result for privately held banks is inconsistent with Hypothesis $1 \mathrm{~b}$.

The explanatory variables in models 3 and 4 exhibit a pattern that persists in all of the remaining analyses in the paper. $N C O$ is positive and significant in both models, but the point estimate for privately held banks is substantially greater than that for publicly held banks. NPTL is also positive in both models, but the point estimate is greater for publicly held banks. These results suggest that loan loss reserves at privately held banks are relatively more responsive to trends in historical loan losses (a more backward-looking metric), while reserves at publicly held banks are relatively more responsive to current changes in non-performing loans (a metric for expected future loan losses).

Models 5 through 8 use the full sample for more direct estimates of the effect of the SunTrust decision on loan loss reserves across ownership structures. Public remains positive, with magnitudes ranging between 10.7 percent and 13.6 percent of the sample median $L L R$. The estimates for AfterST in models 5 and 7 indicate that on average, reserves were lower by about 0.015 percent of assets in the post-SunTrust period. While highly statistically significant, the economic significance is more modest, equaling 1.7 percent of the sample median $L L R$. Model 8, which includes the interaction of Public and AfterST, directly tests Hypotheses 1a and 1b. Public*AfterST is negative and significant, consistent with the level of loan loss reserves for publicly held banks declining relative to loan loss reserves for privately held banks following the SunTrust decision as predicted by Hypothesis 1a. AfterST is no longer significant at conventional levels, suggesting that for privately held banks, the SunTrust decision had no effect on loan loss reserves, as predicted by Hypothesis $1 \mathrm{~b}$. The reduction in $L L R$ associated with AfterST in models 5 and 7 appears to be concentrated exclusively among publicly held banks. 
Based on the coefficient estimate for Public*AfterST, publicly held banks lowered their loan loss reserves by an amount equal to 6 percent of the sample median $L L R$ in the wake of the SunTrust decision.

One concern with the findings in Table 3 is that, given our lengthy sample period, AfterST could reflect changes to loan loss reserves other than those related to the SunTrust decision. Lingering effects of the savings and loan crisis and the recession in the early 1990s, the 2001 recession, the 2001 SR letter (which was the end point for the dialogue between the SEC and banking regulators initiated with the 1998 and 1999 interagency letters - see Section II), or other phenomena could all affect the pattern of loan loss reserves (or provisioning, discussed below) over time and so be captured by AfterST. To address this concern, we performed the analyses of Table 3 again using a much narrower sample period, including just eight quarters before and after the SunTrust decision. Results from these specifications are presented in Table 4 . The pattern of results is extremely similar to those in Table 3 . The coefficient estimate for Public again declines by just under half from model 1 to model 2, consistent with Hypothesis 1a. The absolute value of the point estimate for AfterST is again nearly twice as large in model 3 as in model 4 , although neither is statistically significant. Public*AfterST is negative and significant in model 8, consistent with Hypothesis 1a. The absolute value of the point estimate for Public*AfterST is lower in Table 4, but still implies a reduction in loan loss reserves of publicly held banks equal to 4.4 percent of the sample median following the SunTrust decision. AfterST is not significant in model 4 or 8, consistent with Hypothesis $1 \mathrm{~b}$. Results for the explanatory variables are also similar, although in Table 4 several drop in significance, plausibly due to the reduction in both the number of observations and the variation in some variables over the shorter time horizon. 
Table 5 presents specifications similar to those of Table 3 using the full sample period, but with $P L L$ as the dependent variable in order to test Hypotheses 2a and 2b. Hypothesis 2a predicts that the coefficient estimate for Public should decrease from model 1 (the pre-SunTrust period) to model 2 (the post-SunTrust period), and this prediction is confirmed. There was no statistically significant difference in provisioning across ownership structure in the pre-SunTrust period, but in the post-SunTrust period provisioning by publicly held banks was 0.0202 percent of assets lower than provisioning by privately held banks. This difference is economically substantial, equaling 17 percent of the sample median PLL (0.0202 / 0.119). Models 3 through 7 indicate that, on average, provisioning was higher after the SunTrust decision than before, and over the entire sample period publicly held banks had lower provisioning than privately held banks. Model 8 includes the interaction term Public*AfterST, which is negative and significant and therefore is consistent with Hypothesis 2a. The coefficient estimate on AfterST is positive and significant in models 4 and 8 , which is consistent with Table 2 but contradicts the prediction of Hypothesis $2 \mathrm{~b}$ that provisioning by privately held banks was unaffected by the SunTrust decision.

The coefficient estimate for Public*AfterST in model 8 indicates that following the SunTrust decision, loan loss provisions of publicly held banks were on average 0.0483 percent of average assets lower than those of privately held banks each quarter. While this difference appears quite small as a percentage of assets, its magnitude is equal to 40.6 percent of the sample median $P L L$, nearly a full standard deviation, clearly an economically significant adjustment of provisioning policy. If publicly held banks had not reduced their provisioning relative to privately held banks following the SunTrust decision, they would likely have had substantially higher reserves to better absorb the impact of the recent financial crisis. 
Table 6 repeats the analyses of Table 5 using the narrower sample period of eight quarters before and after the SunTrust decision. A few differences between Tables 5 and 6 are noteworthy. The point estimates for Public drop from model 1 to model 2 in Table 6, but in neither specification is the estimate significant. The estimate for Public*After in model 8 remains negative, consistent with the prediction of Hypothesis 2a. AfterST switches from positive in Table 5 to negative in most models of Table 6 , suggesting that an increase in provisioning associated with the 2001 recession may explain the positive coefficients found using the full sample period. AfterST is not significant for privately held banks in model 4, consistent with Hypothesis 2b; however, it is negative in model 6, which is inconsistent with Hypothesis $2 \mathrm{~b}$ and suggests that provisioning by privately held banks decreased after the SunTrust decision, possibly influenced by their supervisory agencies.

With only one exception, the coefficient estimates for $E B P$ are positive and significant across all models in Tables 5 and 6, indicating that banks increase their provisions for loan losses as their pre-provisioning income increases. As described above, this could indicate the use of provisioning to either smooth income or create an additional cushion in loan loss reserves against future losses. The exception, an insignificant result in model 3 of Table 6, suggests that publicly held banks may not have managed earnings via provisioning as described above, at least during the narrow sample period around the SunTrust decision.

Tables 7 and 8 include interactions of EBP with Public and AfterST to examine further how the relationship between earnings and provisions for loan losses differed across ownership structures and periods. In models 1 and 2 of Table 7, the estimates for EBP*Public indicate no significant differences in earnings management via provisioning across ownership structures in either the pre- or post-SunTrust period. Models 3 and 4 indicate that following the SunTrust 
decision, the relationship between provisions and earnings weakened for privately held banks but not for publicly held banks, contradicting Hypotheses $3 \mathrm{a}$ and $3 \mathrm{~b}$. A plausible explanation is that even prior to the SunTrust decision, SEC oversight, disclosure requirements, and market analyst coverage limited the potential usefulness of earnings management for publicly held banks, so the stricter accounting rules following the SunTrust decision may not have been binding. Privately held banks, with relatively more asymmetric information between insiders and outsiders and therefore more ability to influence investor perceptions through signaling, may have stronger incentives to manage earnings. Such firms may have been influenced to reduce earnings management via loan loss provisioning in the wake of the SunTrust decision.

Models 5 through 8 use the full sample, exploiting variation in both ownership structure and sample period. $E B P^{*}$ Public is consistently negative, indicating that earnings management via provisioning is more prevalent among privately held banks than publicly held banks. This suggests that the greater scope for asymmetric information among privately held firms, which can increase the potency of signals from earnings reports, provides greater incentives for earnings management relative to the incentives of publicly held firms. EBP*AfterST is also consistently negative, suggesting that the stricter adherence to accounting rules following the SunTrust decision was effective at reducing the extent of earnings management via loan loss provisioning. Comparing the coefficient estimates for $E B P$ and $E B P^{*} A f t e r S T$ from model 6 implies that the average amount of provisioning associated with one extra dollar of pre-provision income dropped by 45 percent $(-0.0201 / 0.0446)$ after the SunTrust decision. A Wald test rejects the hypothesis that the sum of those two coefficient estimates equals zero, suggesting that although the relationship between earnings and provisioning weakened after the SunTrust decision, it was not eliminated entirely. The coefficient estimates for $E B P$ and $E B P^{*} A f t e r S T$ 
from models 7 and 8 show similar drops in earnings management following the SunTrust decision. In model $8, E B P * P u b l i{ }^{*} A f t e r S T$ is not significant, suggesting that the weakening of the relationship between earnings and provisions following the SunTrust decision was not concentrated among firms of one ownership structure or the other, contradicting Hypothesis $3 \mathrm{a}$.

Table 8 uses the same specifications as Table 7 for the narrower sample period. The pattern of results is similar to that found in Table 7, except that several coefficient estimates drop in significance. Public*AfterST remains significant in some models, but other variables that relate to AfterST are not significant in any model. The lack of significance for $E B P^{*} A f t e r S T$ in models 4 and 8 is consistent with Hypothesis 3b, but in light of most variables involving AfterST being insignificant, the results may be more reflective of the limited sample period than of the hypothesis.

Overall, Tables 3-8 provide strong support for Hypotheses 1a and 2a. The SunTrust decision is associated with statistically and economically significant reductions in loan loss reserves and provisioning among publicly held banks relative to privately held banks. The evidence regarding Hypotheses $1 \mathrm{~b}$ and $2 \mathrm{~b}$ are more mixed. From some specifications, privately held banks do not appear to have experienced significant reductions in loan loss reserves or provisioning following the SunTrust decision, but other specifications indicate reductions in both. Neither Hypothesis $3 a$ nor $3 b$ are supported by the evidence. The relationship between bank earnings and provisioning does appear to have weakened following the SunTrust decision, but if anything the weakening was concentrated among privately held banks, not publicly held ones.

Section V.3 - Robustness Checks 
We performed several additional analyses to check the robustness of our findings. (These results are all available upon request.) As noted above, the reported results are based on panel regressions with random effects for consistency with previous literature. When we use fixed effects instead, the results are very similar. The main variable of interest that changes is Public. It loses significance in model 2 of Table 3 and all models of Table 5. In Tables 6 and 8, Public is positive in all models except model 2. Public also becomes positive in model 8 of Table 7. In addition, AfterST becomes negative in model 4 of Tables 4 and 6, Public*AfterST becomes negative in model 6 of Table 8 , and $E B P$ loses significance in the first two models of Table 8.

Because our hypotheses rest on comparisons across sample periods, it is possible that the quadratic time trend included in all specifications could influence our findings. To address this concern, we performed the analyses without the time trend variables. As might be expected, AfterST is the key variable that is most affected. AfterST becomes positive and significant in most models in Table 3, in models 4 and 8 of Table 4, and in models 5 through 7 in Table 8 . It loses significance in models 5 and 7 of Table 4 , models 3 and 4 of Table 5, all models in Table 6 , and model 3 of Table 7. In addition, Public loses significance in Table 5, becomes positive in model 8 of Table 7, and Public*AfterST loses significance in model 8 of Table 7. We also repeated the analyses for Tables 3, 5, and 7 after omitting the observations for 1999, on the premise that banks may have required multiple quarters to fully adjust their provisioning policies following the SunTrust decision. ${ }^{33}$ AfterST is no longer significant in Table 3, Public is no longer significant in model 2 of Table 5, and Public and $E B P^{*} P u b l i c$ are no longer significant in models 5 and 7 of Table 7.

\footnotetext{
${ }^{33}$ We do not perform this robustness check for Tables 4, 6 and 8 because doing so would entail dropping a quarter of the total observations.
} 
The level of loan loss reserves could plausibly affect the subsequent magnitudes of loan loss provisions, but including a lagged value of $L L R$ as an explanatory variable in Tables 5 and 6 does not alter the results. Including lagged $L L R$ causes Public to lose significance in Table 7, and Public*After to lose significance in model 7 of Table 8. In recognition that banks may consider more than two years of historical loan losses when determining current provisions, we altered $N C O$ to equal average net charge-offs over the previous 12 quarters instead of eight. In Table 3 this results in AfterST losing significance in models 3 through 7 and becoming positive in model 6. In Table 4, AfterST loses significance in model 4. Changing NCO did not affect Tables 5 or 6 . Public lost significance in Table 7, while Public*After became negative in model 6 of Table 8.

The analyses were repeated using only banks with assets under $\$ 10$ billion to determine whether the paper"s results are driven by a small number of banks whose scale and scope of operations may be qualitatively different from those of smaller banks. Dropping the largest banks causes only limited changes to the variables of interest. AfterST becomes negative in model 8 of Table 3 and loses significance in model 8 of Table 6 . Public becomes positive in model 8 of both Tables 7 and 8. Public*AfterST loses significance in model 8 of Table 7 and becomes negative in model 6 of Table 8, and EBP*Public becomes negative in model 8 of Table 8. It is also possible that the approximately 3 percent of publicly traded banks that are not on any of the three largest exchanges (NYSE, AMEX, and NASDAQ) are not representative of the 97 percent that are. Dropping the observations for publicly traded banks not on one of the major exchanges caused no changes in Tables 3 through 5. AfterST loses significance in model 8 of Table 6. Public is no longer significant in Table 7, and EBP*Public loses significance in model 8 of Table 7. In Table 8, Public*AfterST becomes negative in model 6. 
Our provisioning results could be influenced by a quarterly pattern in the percentage of observations with loan loss provisioning equal to zero. Nearly 29 percent of first-quarter observations show a provision of zero, and that percentage declines steadily to around 15 percent of fourth-quarter observations. Zero could be the most appropriate provision value for a given bank in a given quarter, but a zero provision could also indicate a bank that as a matter of policy provisions less frequently than quarterly. To try to minimize the effect of zero provisioning as a matter of policy without dropping all zero provisioning observations, we repeated the analyses using only fourth-quarter observations, the rationale being that if a bank provisions only in one quarter during the year, anecdotal evidence and the sample characteristics just described suggest that it is likeliest to provision in the fourth quarter. AfterST is not significant in model 7 of Table 3 , is positive in most models of Tables 4 and 6 , and is negative in model 5 of Table 8. Public loses significance in model 2 of Table 5 and throughout Table 8. It becomes positive throughout Table 6, and becomes negative in models 1 and 8 of Table 5, and in model 6 of Table 7 . Public*After loses significance in most models of Tables 7 and 8. EBP*Public loses significance in model 5 of Table 7 and throughout Table 8.

Summarizing the robustness checks with respect to our main hypotheses, the results for the variable with which we test Hypotheses 1a and 2a, Public*AfterST, do not change in Tables 3 through 6 in any of the robustness checks described above, consistently supporting both hypotheses. The variable ees results do change in Tables 7 and 8 , sometimes losing significance (weakening support for Hypothesis 2a) and sometimes becoming negative and significant (strengthening support for Hypothesis 2a). EBP*Public*AfterST remains insignificant in all of our robustness checks, consistently contradicting Hypothesis $3 \mathrm{a}$. 


\section{Section VI - Conclusion}

This paper examines how the tightening of accounting constraints associated with the SunTrust decision impacted the loan loss reserve policies of banks differently based on ownership structure. The SunTrust decision, being the result of an SEC inquiry, placed more binding constraints on publicly held bank than on privately held banks. The evidence presented here indicates that, all else equal, publicly held banks held higher levels of loan loss reserves as a percentage of assets relative to privately held banks, but the difference across ownership structures significantly narrowed following the SunTrust decision. Publicly held banks lowered both their levels of loan loss reserves and their provisioning for loan losses relative to privately held banks. Evidence also indicates that the positive relationship between bank earnings and loan loss provisioning weakened in the wake of the SunTrust decision, consistent with a reduction in either income smoothing or early recognition of loan losses during good economic times. That weakening appears concentrated among privately held banks, potentially due to privately held banks having relatively greater incentive to manage earnings, and so constraints on earnings management are more binding for privately held banks than publicly held banks. Together, these findings suggest that the stricter accounting constraints associated with the SunTrust decision contributed to an overall lowering of loan loss reserves in the years leading up to the recent financial crisis. In the aftermath of the 2007-2009 experience, the Basel Committee on Banking Supervision has incorporated countercyclical tools, including strong recommendations for forward-looking loan loss provisions, in the new Basel III capital framework. The experience of the 1990s described in this paper suggests that banker incentives may well be aligned for a move to a more forward-looking loan loss provisioning approach. 


\section{References}

Adams, B., Carow, K.A., Perry, T., 2009. Earnings management and initial public offerings: The case of the depository institution. Journal of Banking and Finance 33, 2363-2372.

Ahmed, A.S., Takeda, C., Thomas, S., 1999. Bank loan loss provisions: A reexamination of capital management, earnings management, and signaling effects. Journal of Accounting and Economics 28, 1-25.

Arrellano, M., Bond S. 1991. Some tests of specification for panel data: Monte Carlo evidence and an application to employment equation. Review of Economic Studies, 58. 277-297.

Balla, E. McKenna, A. 2009. Dynamic Provisioning: A Countercyclical tool for loan loss reserves. Economic Quarterly Federal Reserve Bank of Richmond, Fall, 383-418.

Basel Committee on Banking Supervision, 2011. Basel III: a Global Regulatory Framework for More Resilient Banks and Banking Systems.

Basel Committee on Banking Supervision, 2006. Basel II: International convergence of capital measurement and capital standards: A revised framework - comprehensive version.

Beatty, A.L., Ke, B., Petroni, K.R., 2002. Earnings management to avoid earnings declines across publicly and privately held banks. The Accounting Review 77, 547-570.

Benston, G.J., Wall, L.D., 2005. How should banks account for loan losses? Federal Reserve Bank of Atlanta Economic Review, Fourth Quarter, 19-38.

Berger, A.N., Udell, G.F., 2003. The institutional memory hypothesis and the procyclicality of bank lending behavior. Journal of Financial Intermediation 13, 458-495.

Bernanke, Ben. Financial reforms to address systemic risk. Remarks before the Council on Foreign Relations, Washington, D.C., March 10, 2009.

Bouvatier, V., Lepetit, L., 2008. Banks ${ }^{\text {ee }}$ procyclical behavior: Does provisioning matter? Journal of International Financial Markets, Institutions, and Money 18, 513-526.

Dugan, J. Loan loss provisioning and procyclicality. Remarks before the Institute of International Bankers, Washington, D.C., March 2, 2009.

Financial Accounting Standards Board, March 1973. Summary of Statement No. 5: Accounting for contingencies.

Financial Accounting Standards Board, May 1993. Statement of Financial Accounting Standards No. 114: Accounting by Creditors for Impairment of a Loan - an amendment of FASB Statements No. 5 and 15. 
Financial Accounting Standards Board. May 26, 2010. Proposed Accounting Standards Update- - Accounting for Financial Instruments and Revisions to the Accounting for Derivative Instruments and Hedging Activities."

Fonseca, A.R., Gonzalez, F., 2008. Cross-country determinants of bank income smoothing by managing loan-loss provisions. Journal of Banking and Finance 32, 217-228.

Foos, D., Norden, L., Weber, M., 2010. Loan growth and riskiness of banks. Journal of Banking and Finance 34, 2929-2940.

Greenwald, M.B., Sinkey Jr. J. F., 1988. Bank loan loss provisions and the income smoothing hypothesis: an empirical analysis, 1976-1984. Journal of Financial Services Research, 1, 301318.

Gunther, J.W., Moore, R.R., 2003a. Early warning models in real time. Journal of Banking and Finance 27, 1979-2001.

Gunther, J.W., Moore, R.R., 2003b. Loss underreporting and the auditing role of bank exams. Journal of Financial Intermediation 12, 153-177.

Holod, D., Peek, J., 2007. Asymmetric information and liquidity constraints. Journal of Banking and Finance 31, 2415-2451.

Keeton, W., 1999. Does faster loan growth lead to higher loan losses? The Federal Reserve Bank of Kansas City Economic Review, Second Quarter, 57-75.

Kwan, S.H., 2004. Risk and return of publicly held versus privately owned banks. The Federal Reserve Bank of New York Economic Policy Review, September, 97-107.

Laeven, L., Majnoni, G., 2003. Loan loss provisioning and economic slowdowns: Too much, too late? Journal of Financial Intermediation 12, 178-197.

Nichols, D.C., Wahlen, J.M., Wieland, M.M., 2009. Publicly traded versus privately held: Implications for conditional conservatism in bank accounting. Review of Accounting Studies $14,88-122$.

Rajan, R., 1994. Why bank credit policies fluctuate: A theory and some evidence. The Quarterly Journal of Economics 109, 399-441.

Supervision and Regulation Letter 06-17: Interagency Policy Statement on the ALLL, Board of Governors, Federal Reserve System, December 13, 2006.

Supervision and Regulation Letter 01-17: Policy Statement on ALLL Methodologies and Documentation for Banks and Savings Institutions, Board of Governors, Federal Reserve System, July 2, 2001. 
Supervision and Regulation Letter 99-22: Joint Interagency Letter on the Loan Loss Allowance, Board of Governors, Federal Reserve System, July 26, 1999.

Wall, L.D., Koch, T.W., 2000. Bank loan loss accounting: A review of theoretical and empirical evidence. Federal Reserve Bank of Atlanta Economic Review, Second Quarter, 1-19.

Wahlen, J. (1994). The nature of information in commercial bank loan loss disclosures. The Accounting Review 69, 455-478.

Walter, J., 1991. Loan loss reserves. Federal Reserve Bank of Richmond 'es Economic Review $77,20-30$. 


\section{Figure 1}

Loan loss provisions as a percentage of pre-provision, pre-tax earnings. This figure indicates the quarterly sample average of loan loss provisions as a percentage of pre-provision earnings. Loan loss provision and pre-provision earnings data are from Call Reports. Percentages are winsorized at the $1^{\text {st }}$ and $99^{\text {th }}$ percentiles to avoid distortions due to extreme values.

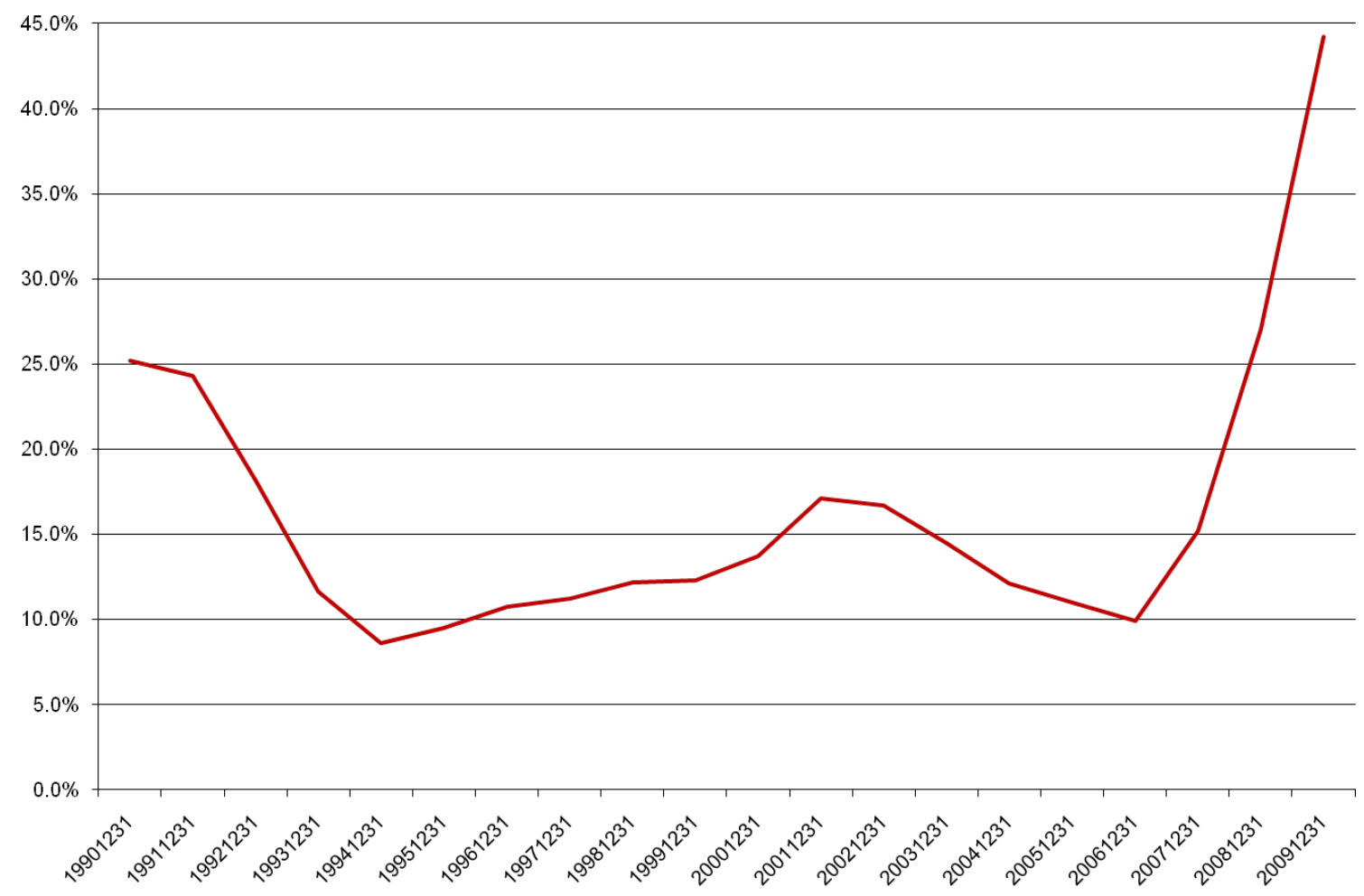




\section{Figure 2}

Distribution of Public. This figure shows the percentage of banks that were publicly held in the fourth quarter of each indicated year, for the full sample and for banks divided by size at $\$ 1$ billion and $\$ 10$ billion in total assets.

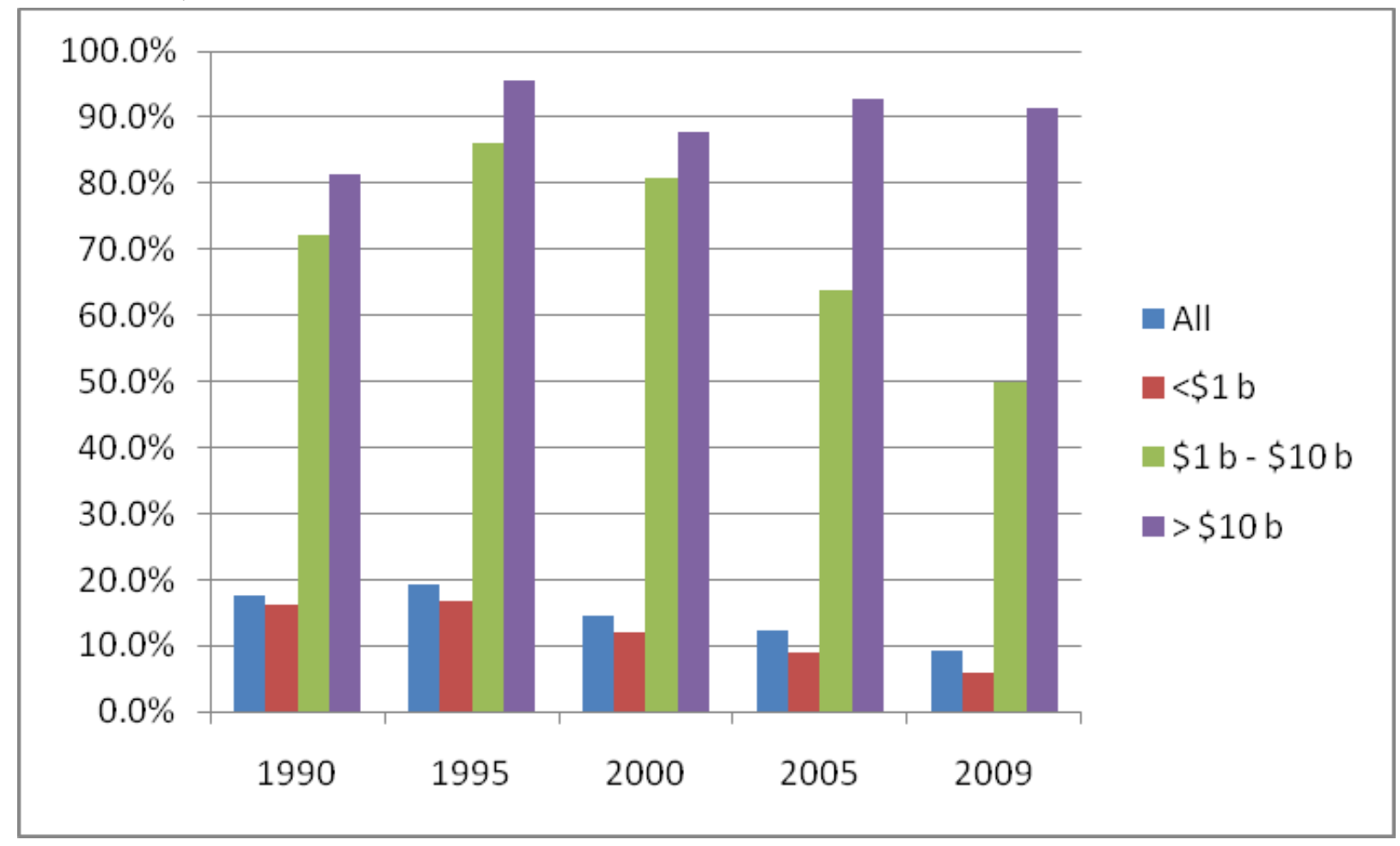




\section{Table 1}

Summary statistics. $L L R$ is loan loss reserves. PLL is provision for loan losses. AfterST equals 1 after 1998Q4, 0 otherwise. Public equals 1 if the firm is publicly traded or if the bank-holding company or financial-holding company owning the firm are publicly traded, 0 otherwise. $N C O$ is the average value over the previous eight quarters of net charge-offs as a percentage of average assets from the previous quarter. NPTL is non-performing loans. $\triangle$ Loans is change in total loans. EBP is earnings before provisions and taxes. $E Q$ is shareholder equity. Size is the natural log of total assets (in thousands) in the previous quarter. $\triangle G D P$ is percentage change in real GDP in the previous quarter. DeNovo equals 1 in the first five years of the firm "s life, 0 otherwise. Fail equals 1 in the final quarter of the firm "s existence and the previous three quarters, 0 otherwise. Merger equals 1 if the firm merged with another firm during the current quarter, 0 otherwise. LLR, NPTL, $\triangle$ Loans, and EQ are expressed as percentages of total assets from the previous quarter. $P L L$ and $E B P$ are expressed as percentages of average assets from the previous quarter.

\begin{tabular}{lrrrrr}
\hline Variable & Mean & Std. Dev. & $25^{\text {th }}$ percentile & Median & $75^{\text {th }}$ percentile \\
\hline LLR & 0.933 & 0.508 & 0.648 & 0.848 & 1.093 \\
PLL & 0.215 & 0.467 & 0.003 & 0.119 & 0.261 \\
AfterST & 0.487 & 0.500 & 0 & 0 & 1 \\
Public & 0.160 & 0.367 & 0 & 0 & 0 \\
NCO & 0.166 & 0.431 & 0.012 & 0.070 & 0.192 \\
NPTL & 0.671 & 0.856 & 0.129 & 0.400 & 0.882 \\
ALoans & 1.590 & 6.225 & -0.385 & 1.091 & 2.851 \\
EBP & 1.871 & 1.358 & 1.351 & 1.818 & 2.291 \\
EQ & 10.371 & 4.062 & 8.099 & 9.439 & 11.516 \\
Size & 11.363 & 1.302 & 10.517 & 11.215 & 11.993 \\
$\Delta$ GDP & 0.795 & 0.475 & 0.500 & 0.769 & 1.063 \\
DeNovo & 0.052 & 0.222 & 0 & 0 & 0 \\
Fail & 0.001 & 0.027 & 0 & 0 & 0 \\
Merger & 0.010 & 0.101 & 0 & 0 & 0 \\
\hline Number of institutions & 13,317 & & \\
Number of observations & 517,822 & & \\
\hline
\end{tabular}


Table 2

Differences of means of $L L R$ and $P L L$ by bank type and sample period. $L L R$ is loan loss reserves as a percentage of total assets from the previous quarter. $P L L$ is provision for loan losses as a percentage of average assets from the previous quarter. The pre-SunTrust and post-SunTrust sample periods are 1992Q1-1998Q3 and 1999Q1-2007Q2, respectively. Significance levels and t-statistics in brackets are from t-tests of differences in means. All differences of means are significant at the 1 percent level.

\begin{tabular}{|c|c|c|c|}
\hline \multicolumn{4}{|c|}{ Panel A: Means of LLR } \\
\hline & Public banks & Private banks & Difference in means \\
\hline \multirow[t]{2}{*}{ Pre-SunTrust } & 1.111 & 0.919 & $0.192 * * *$ \\
\hline & & & {$[71.089]$} \\
\hline \multirow[t]{2}{*}{ Post-SunTrust } & 0.984 & 0.899 & $0.085 * * *$ \\
\hline & & & {$[31.460]$} \\
\hline \multirow[t]{2}{*}{ Difference in means } & $0.127 * * *$ & $0.020 * * *$ & \\
\hline & [29.212] & [13.815] & \\
\hline \multicolumn{4}{|c|}{ Panel B: Means of PLL } \\
\hline & Public banks & Private banks & Difference in means \\
\hline \multirow[t]{2}{*}{ Pre-SunTrust } & 0.290 & 0.198 & $0.093 * * *$ \\
\hline & & & {$[37.467]$} \\
\hline \multirow[t]{2}{*}{ Post-SunTrust } & 0.279 & 0.206 & $0.072 * * *$ \\
\hline & & & {$[28.592]$} \\
\hline \multirow[t]{2}{*}{ Difference in means } & $0.011 * * *$ & $-0.009 * * *$ & \\
\hline & {$[2.786]$} & {$[-6.611]$} & \\
\hline
\end{tabular}


Table 3

Panel regressions of loan loss reserves ( $L L R)$ using the full sample period. The sample periods for models 1 and 2 are 1992Q1-1998Q3 and 1999Q1-2007Q2, respectively. The sample period for models 3-8 is 1992Q1-2007Q2, with 1998Q4 (the quarter in which the SunTrust decision occurred) excluded. Variables are as defined in Table 1. Specifications include random effects by bank, robust standard errors, quarter dummies, quadratic time trend variables, and a constant term. T-statistics appear in brackets. Levels of significance are indicated by ***, and *** for $10 \%, 5 \%$, and $1 \%$, respectively.

\begin{tabular}{|c|c|c|c|c|c|c|c|c|}
\hline & (1) & (2) & (3) & (4) & (5) & (6) & (7) & $(8)$ \\
\hline & Pre-SunTrust & Post-SunTrust & Public banks & Private banks & All observations & All observations & All observations & All observations \\
\hline \multirow[t]{2}{*}{ Public } & $0.136^{* * *}$ & $0.0718^{* * *}$ & & & & $0.0912 * * *$ & $0.0910^{* * *}$ & $0.115 * * *$ \\
\hline & [10.88] & {$[3.861]$} & & & & {$[7.950]$} & [7.940] & {$[9.210]$} \\
\hline \multirow[t]{2}{*}{ AfterST } & & & $-0.0285 * *$ & $-0.0134 * * *$ & $-0.0148 * * *$ & & $-0.0145 * * *$ & -0.00644 \\
\hline & & & {$[-2.329]$} & {$[-3.176]$} & {$[-3.447]$} & & {$[-3.389]$} & {$[-1.401]$} \\
\hline \multirow[t]{2}{*}{ Public*AfterST } & & & & & & & & $-0.0508 * * *$ \\
\hline & & & & & & & & {$[-4.058]$} \\
\hline \multirow[t]{2}{*}{$E B P$} & 0.00611 & $0.0123 * * *$ & 0.00654 & $0.00958 * * *$ & $0.00911 * * *$ & $0.00965 * * *$ & $0.00954 * * *$ & $0.00969 * * *$ \\
\hline & [1.193] & [4.022] & {$[0.963]$} & {$[2.866]$} & {$[2.790]$} & {$[2.944]$} & {$[2.914]$} & {$[2.965]$} \\
\hline \multirow[t]{2}{*}{$\mathrm{NCO}$} & $0.156 * * *$ & $0.0982 * * *$ & $0.0860 * *$ & $0.193 * * *$ & $0.156^{* * *}$ & $0.156^{* * *}$ & $0.156 * * *$ & $0.156^{* * *}$ \\
\hline & {$[5.346]$} & {$[3.052]$} & {$[2.361]$} & [10.83] & {$[5.555]$} & {$[5.563]$} & {$[5.556]$} & {$[5.552]$} \\
\hline \multirow[t]{2}{*}{$N P T L$} & $0.119 * * *$ & $0.120 * * *$ & $0.240 * * *$ & $0.121 * * *$ & $0.139 * * *$ & $0.139 * * *$ & $0.139 * * *$ & $0.139 * * *$ \\
\hline & {$[27.56]$} & {$[28.53]$} & {$[20.26]$} & {$[37.15]$} & {$[36.13]$} & {$[36.15]$} & {$[36.20]$} & {$[36.26]$} \\
\hline \multirow[t]{2}{*}{$\Delta$ Loans } & $0.00903 * * *$ & $0.00623 * * *$ & $0.0109 * * *$ & $0.00480 * * *$ & $0.00779 * * *$ & $0.00779 * * *$ & $0.00779 * * *$ & $0.00777 * * *$ \\
\hline & [18.92] & [11.29] & [19.44] & [10.57] & [19.71] & [19.74] & [19.75] & {$[19.71]$} \\
\hline \multirow[t]{2}{*}{$E Q$} & 0.00188 & $0.00300 *$ & -0.000697 & 0.00258 & 0.00186 & 0.00147 & 0.00138 & 0.00158 \\
\hline & [1.415] & [1.815] & {$[-0.277]$} & [1.590] & [1.402] & [1.105] & [1.034] & [1.188] \\
\hline \multirow[t]{2}{*}{ Size } & $-0.0781 * * *$ & $-0.0593 * * *$ & $-0.0334^{*}$ & $-0.0486 * * *$ & $-0.0442 * * *$ & $-0.0521 * * *$ & $-0.0517 * * *$ & $-0.0478 * * *$ \\
\hline & {$[-8.607]$} & {$[-8.497]$} & {$[-1.843]$} & {$[-5.576]$} & {$[-5.829]$} & {$[-6.667]$} & {$[-6.620]$} & {$[-6.118]$} \\
\hline \multirow[t]{2}{*}{$\triangle G D P$} & $-0.0031 * * *$ & $0.0038 * * *$ & $-0.00806 * * *$ & $-0.00151 *$ & $-0.0028 * * *$ & $-0.0026^{* * *}$ & $-0.0029 * * *$ & $-0.0028 * * *$ \\
\hline & {$[-3.134]$} & [3.444] & {$[-3.020]$} & {$[-1.664]$} & {$[-3.167]$} & {$[-2.859]$} & {$[-3.346]$} & {$[-3.181]$} \\
\hline \multirow[t]{2}{*}{ DeNovo } & -0.0109 & $-0.0319 * * *$ & -0.0288 & $-0.0259 * * *$ & $-0.0303 * * *$ & $-0.0284 * * *$ & $-0.0267 * * *$ & $-0.0271 * * *$ \\
\hline & {$[-0.806]$} & {$[-3.638]$} & {$[-1.266]$} & {$[-2.710]$} & {$[-3.314]$} & {$[-3.119]$} & {$[-2.913]$} & {$[-2.968]$} \\
\hline \multirow[t]{2}{*}{ Fail } & $0.383 * * *$ & $0.248 * * *$ & $0.638 * *$ & $0.306 * * *$ & $0.352 * * *$ & $0.354 * * *$ & $0.354 * * *$ & $0.356 * * *$ \\
\hline & [3.826] & {$[2.718]$} & [2.116] & [3.816] & [4.208] & [4.223] & [4.224] & [4.220] \\
\hline \multirow[t]{2}{*}{ Merger } & $0.131 * * *$ & $0.144 * * *$ & $0.0586^{* * *}$ & $0.214 * * *$ & $0.141 * * *$ & $0.139 * * *$ & $0.139 * * *$ & $0.139 * * *$ \\
\hline & [12.08] & [12.05] & [5.374] & [18.24] & {$[15.30]$} & {$[15.16]$} & [15.19] & {$[15.17]$} \\
\hline Observations & 265,500 & 252,322 & 82,983 & 434,839 & 517,822 & 517,822 & 517,822 & 517,822 \\
\hline Banks & 11,927 & 9,441 & 3,865 & 10,989 & 13,317 & 13,317 & 13,317 & 13,317 \\
\hline $\mathrm{R}^{2}$ & 0.187 & 0.16 & 0.268 & 0.194 & 0.195 & 0.208 & 0.209 & 0.214 \\
\hline
\end{tabular}


Table 4

Panel regressions of loan loss reserves (LLR) using a narrow sample period. The sample periods for models 1 and 2 are 1996Q4-1998Q3 and 1999Q1-2000Q4, respectively. The sample period for models 3-8 is 1996Q4-2000Q4, with 1998Q4 (the quarter in which the SunTrust decision occurred) excluded. Variables are as defined in Table 1. Specifications include random effects by bank, robust standard errors, quarter dummies, quadratic time trend variables, and a constant term. T-statistics appear in brackets. Levels of significance are indicated by ***, and *** for $10 \%, 5 \%$, and $1 \%$, respectively.

\begin{tabular}{|c|c|c|c|c|c|c|c|c|}
\hline & (1) & (2) & (3) & (4) & (5) & (6) & (7) & $(8)$ \\
\hline & Pre-SunTrust & Post-SunTrust & Public banks & Private banks & All observations & All observations & All observations & All observations \\
\hline \multirow[t]{2}{*}{ Public } & $0.178 * * *$ & $0.0926^{* * *}$ & & & & $0.128 * * *$ & $0.128 * * *$ & $0.148 * * *$ \\
\hline & [6.729] & {$[5.253]$} & & & & [7.608] & {$[7.627]$} & {$[8.464]$} \\
\hline \multirow[t]{2}{*}{ AfterST } & & & -0.0107 & -0.00581 & $-0.0097 * * *$ & & $-0.0105 * * *$ & -0.00425 \\
\hline & & & {$[-1.385]$} & {$[-1.499]$} & {$[-2.745]$} & & {$[-2.976]$} & {$[-1.135]$} \\
\hline \multirow[t]{2}{*}{ Public*AfterST } & & & & & & & & $-0.0371 * * *$ \\
\hline & & & & & & & & {$[-3.902]$} \\
\hline \multirow[t]{2}{*}{$E B P$} & 0.015 & $0.00734 *$ & 0.00551 & $0.0133 * *$ & $0.00990 *$ & $0.0106^{*}$ & $0.0105^{*}$ & $0.0106^{*}$ \\
\hline & [1.407] & [1.905] & {$[0.445]$} & {$[2.306]$} & {$[1.793]$} & [1.904] & {$[1.884]$} & [1.918] \\
\hline \multirow[t]{2}{*}{$\mathrm{NCO}$} & $0.117 * * *$ & $0.0399 *$ & $0.0420^{*}$ & $0.154 * * *$ & $0.0809 * * *$ & $0.0808 * * *$ & $0.0808 * * *$ & $0.0804 * * *$ \\
\hline & [6.955] & [1.901] & {$[1.805]$} & {$[5.545]$} & {$[2.812]$} & {$[2.806]$} & {$[2.807]$} & {$[2.808]$} \\
\hline \multirow[t]{2}{*}{$N P T L$} & $0.0847 * * *$ & $0.0804 * * *$ & $0.173 * * *$ & $0.0873 * * *$ & $0.0988 * * *$ & $0.0988 * * *$ & $0.0989 * * *$ & $0.0987 * * *$ \\
\hline & [13.64] & {$[15.76]$} & [9.243] & {$[17.47]$} & {$[19.17]$} & {$[19.23]$} & {$[19.23]$} & [19.22] \\
\hline \multirow[t]{2}{*}{$\Delta$ Loans } & $0.00943 * * *$ & $0.00796 * * *$ & $0.0102 * * *$ & $0.00625 * * *$ & $0.00847 * * *$ & $0.00848 * * *$ & $0.00849 * * *$ & $0.00848 * * *$ \\
\hline & [12.24] & [12.31] & [11.90] & [8.307] & [13.83] & [13.82] & [13.84] & [13.83] \\
\hline \multirow[t]{2}{*}{$E Q$} & $0.00910 * * *$ & $0.0141 * * *$ & $0.0104 * * *$ & $0.00791 * * *$ & $0.00898 * * *$ & $0.00821 * * *$ & $0.00812 * * *$ & $0.00824 * * *$ \\
\hline & {$[4.536]$} & [6.080] & {$[2.735]$} & [3.889] & [5.062] & [4.616] & {$[4.553]$} & {$[4.631]$} \\
\hline \multirow[t]{2}{*}{ Size } & $-0.0235 * *$ & $-0.0163 * *$ & 0.00793 & $-0.0354 * * *$ & -0.00554 & $-0.0219 * *$ & $-0.0219 * *$ & $-0.0200 * *$ \\
\hline & {$[-2.469]$} & {$[-2.041]$} & {$[0.459]$} & {$[-2.718]$} & {$[-0.619]$} & {$[-2.248]$} & {$[-2.254]$} & {$[-2.041]$} \\
\hline \multirow[t]{2}{*}{$\triangle G D P$} & -0.00419 & 0.000543 & -0.00304 & 0.00033 & -0.000403 & $-0.00192 * *$ & -0.000371 & -0.000374 \\
\hline & {$[-1.538]$} & {$[0.513]$} & {$[-1.283]$} & {$[0.331]$} & {$[-0.430]$} & {$[-2.018]$} & {$[-0.396]$} & [-0.399] \\
\hline \multirow[t]{2}{*}{ DeNovo } & -0.0122 & 0.00138 & $-0.0683^{*}$ & -0.00489 & -0.0204 & -0.021 & -0.0208 & -0.0203 \\
\hline & {$[-0.611]$} & {$[0.0548]$} & {$[-1.682]$} & {$[-0.227]$} & {$[-1.044]$} & {$[-1.076]$} & {$[-1.068]$} & {$[-1.039]$} \\
\hline \multirow[t]{2}{*}{ Fail } & 0.102 & $0.303 * *$ & 0.800 & 0.137 & $0.221 *$ & $0.216^{*}$ & $0.216^{*}$ & $0.215^{*}$ \\
\hline & {$[0.928]$} & {$[2.300]$} & [0.929] & [1.141] & [1.744] & {$[1.700]$} & [1.699] & [1.689] \\
\hline \multirow[t]{2}{*}{ Merger } & $0.0999 * * *$ & $0.101 * * *$ & $0.0332 *$ & $0.205 * * *$ & $0.117 * * *$ & $0.116^{* * *}$ & $0.116 * * *$ & $0.115 * * *$ \\
\hline & {$[4.658]$} & {$[6.070]$} & [1.938] & [8.649] & [7.483] & [7.394] & [7.394] & [7.361] \\
\hline Observations & 69,401 & 63,145 & 21,821 & 110,725 & 132,546 & 132,546 & 132,546 & 132,546 \\
\hline Banks & 9,303 & 8,459 & 2,230 & 7,977 & 9,723 & 9,723 & 9,723 & 9,723 \\
\hline $\mathrm{R}^{2}$ & 0.185 & 0.145 & 0.202 & 0.177 & 0.179 & 0.183 & 0.183 & 0.184 \\
\hline
\end{tabular}


Table 5

Panel regressions of provisions for loan losses (PLL) using the full sample period. The sample periods for models 1 and 2 are 1992Q1-1998Q3 and 1999Q12007Q2, respectively. The sample period for models 3-8 is 1992Q1-2007Q2, with 1998Q4 (the quarter in which the SunTrust decision occurred) excluded.

Variables are as defined in Table 1. Specifications include random effects by bank, robust standard errors, quarter dummies, quadratic time trend variables, and a constant term. T-statistics appear in brackets. Levels of significance are indicated by *, **, and *** for $10 \%, 5 \%$, and $1 \%$, respectively.

\begin{tabular}{|c|c|c|c|c|c|c|c|c|}
\hline & (1) & (2) & (3) & (4) & (5) & (6) & (7) & (8) \\
\hline & Pre-SunTrust & Post-SunTrust & Public banks & Private banks & All observations & All observations & All observations & All observations \\
\hline \multirow[t]{2}{*}{ Public } & $-7.31 \mathrm{E}-05$ & $-0.0202 *$ & & & & $-0.0195^{* *}$ & $-0.0191 * *$ & 0.00163 \\
\hline & {$[-0.00665]$} & {$[-1.932]$} & & & & {$[-2.406]$} & {$[-2.350]$} & {$[0.180]$} \\
\hline \multirow[t]{2}{*}{ AfterST } & & & $0.0711 * * *$ & $0.0370 * * *$ & $0.0459 * * *$ & & $0.0458 * * *$ & $0.0536^{* * *}$ \\
\hline & & & {$[5.711]$} & [8.009] & {$[10.21]$} & & [10.19] & {$[11.44]$} \\
\hline \multirow{2}{*}{ Public*AfterST } & & & & & & & & $-0.0483 * * *$ \\
\hline & & & & & & & & {$[-5.623]$} \\
\hline \multirow[t]{2}{*}{$E B P$} & $0.0348 * * *$ & $0.0352 * * *$ & $0.0270 * * *$ & $0.0382 * * *$ & $0.0336^{* * *}$ & $0.0331 * * *$ & $0.0335 * * *$ & $0.0336^{* * *}$ \\
\hline & {$[5.707]$} & {$[6.886]$} & {$[4.081]$} & {$[7.785]$} & {$[8.187]$} & [8.109] & {$[8.166]$} & {$[8.186]$} \\
\hline \multirow[t]{2}{*}{$\mathrm{NCO}$} & $0.164 * * *$ & $0.122 * * *$ & $0.0915 * * *$ & $0.219 * * *$ & $0.174 * * *$ & $0.176^{* * *}$ & $0.174 * * *$ & $0.174 * * *$ \\
\hline & {$[6.954]$} & [4.172] & [3.214] & {$[10.88]$} & {$[6.497]$} & {$[6.528]$} & {$[6.496]$} & {$[6.496]$} \\
\hline \multirow[t]{2}{*}{$N P T L$} & $0.119 * * *$ & $0.122 * * *$ & $0.195 * * *$ & $0.111 * * *$ & $0.124 * * *$ & $0.125 * * *$ & $0.124 * * *$ & $0.124 * * *$ \\
\hline & {$[24.46]$} & {$[26.00]$} & [17.22] & {$[30.62]$} & [31.54] & [31.47] & {$[31.51]$} & [31.53] \\
\hline \multirow[t]{2}{*}{$\Delta$ Loans } & $0.00175 * * *$ & $0.00216^{* * *}$ & $0.00202 * * *$ & $0.00207 * * *$ & $0.00227 * * *$ & $0.00228 * * *$ & $0.00227 * * *$ & $0.00225 * * *$ \\
\hline & {$[4.212]$} & {$[5.568]$} & [4.364] & {$[4.975]$} & {$[7.401]$} & {$[7.456]$} & {$[7.401]$} & {$[7.336]$} \\
\hline \multirow[t]{2}{*}{$E Q$} & $-0.0160 * * *$ & $-0.00931 * * *$ & $-0.00911 * * *$ & $-0.0154 * * *$ & $-0.0136 * * *$ & $-0.0138 * * *$ & $-0.0135 * * *$ & $-0.0134 * * *$ \\
\hline & {$[-8.723]$} & {$[-6.673]$} & {$[-4.005]$} & {$[-9.615]$} & {$[-10.28]$} & {$[-10.42]$} & {$[-10.18]$} & {$[-10.04]$} \\
\hline \multirow[t]{2}{*}{ Size } & $0.0492 * * *$ & $0.0389 * * *$ & $0.0533^{* * *}$ & $0.0661 * * *$ & $0.0502 * * *$ & $0.0529 * * *$ & $0.0522 * * *$ & $0.0548^{* * *}$ \\
\hline & [9.201] & [8.379] & [4.123] & {$[10.45]$} & {$[10.46]$} & {$[10.43]$} & [10.26] & [10.62] \\
\hline \multirow[t]{2}{*}{$\triangle G D P$} & $0.0041 * *$ & $-0.0104 * * *$ & $-0.00896 * * *$ & $-0.00640 * * *$ & $-0.0069 * * *$ & $-0.0080 * * *$ & $-0.0069 * * *$ & $-0.0067 * * *$ \\
\hline & {$[2.174]$} & {$[-7.231]$} & {$[-2.848]$} & {$[-4.923]$} & {$[-5.747]$} & {$[-6.604]$} & {$[-5.719]$} & {$[-5.598]$} \\
\hline \multirow[t]{2}{*}{ DeNovo } & $0.148 * * *$ & $0.161 * * *$ & $0.134 * * *$ & $0.189 * * *$ & $0.178 * * *$ & $0.182 * * *$ & $0.177 * * *$ & $0.177 * * *$ \\
\hline & [9.402] & [18.35] & [4.737] & {$[17.57]$} & [17.93] & [18.57] & {$[17.88]$} & {$[17.84]$} \\
\hline \multirow[t]{2}{*}{ Fail } & $0.346^{* *}$ & $0.401 * * *$ & 0.347 & $0.426 * * *$ & $0.427 * * *$ & $0.427 * * *$ & $0.426 * * *$ & $0.428 * * *$ \\
\hline & {$[2.238]$} & {$[3.076]$} & [1.382] & [3.498] & {$[3.755]$} & {$[3.760]$} & {$[3.750]$} & [3.765] \\
\hline \multirow[t]{2}{*}{ Merger } & 0.00902 & -0.0143 & -0.0152 & -0.0102 & -0.0111 & -0.00994 & -0.0107 & -0.0111 \\
\hline & {$[0.816]$} & {$[-1.181]$} & {$[-1.499]$} & {$[-0.789]$} & {$[-1.305]$} & {$[-1.166]$} & {$[-1.262]$} & {$[-1.304]$} \\
\hline Observations & 265,500 & 252,322 & 82,983 & 434,839 & 517,822 & 517,822 & 517,822 & 517,822 \\
\hline Banks & 11,927 & 9,441 & 3,865 & 10,989 & 13,317 & 13,317 & 13,317 & 13,317 \\
\hline $\mathrm{R}^{2}$ & 0.216 & 0.213 & 0.218 & 0.204 & 0.216 & 0.215 & 0.216 & 0.214 \\
\hline
\end{tabular}


Table 6

Panel regressions of provisions for loan losses (PLL) using a narrow sample period. The sample periods for models 1 and 2 are 1996Q4-1998Q3 and 1999Q12000Q4, respectively. The sample period for models 3-8 is 1996Q4-2000Q4, with 1998Q4 (the quarter in which the SunTrust decision occurred) excluded.

Variables are as defined in Table 1. Specifications include random effects by bank, robust standard errors, quarter dummies, quadratic time trend variables, and a constant term. T-statistics appear in brackets. Levels of significance are indicated by *, **, and *** for $10 \%, 5 \%$, and $1 \%$, respectively.

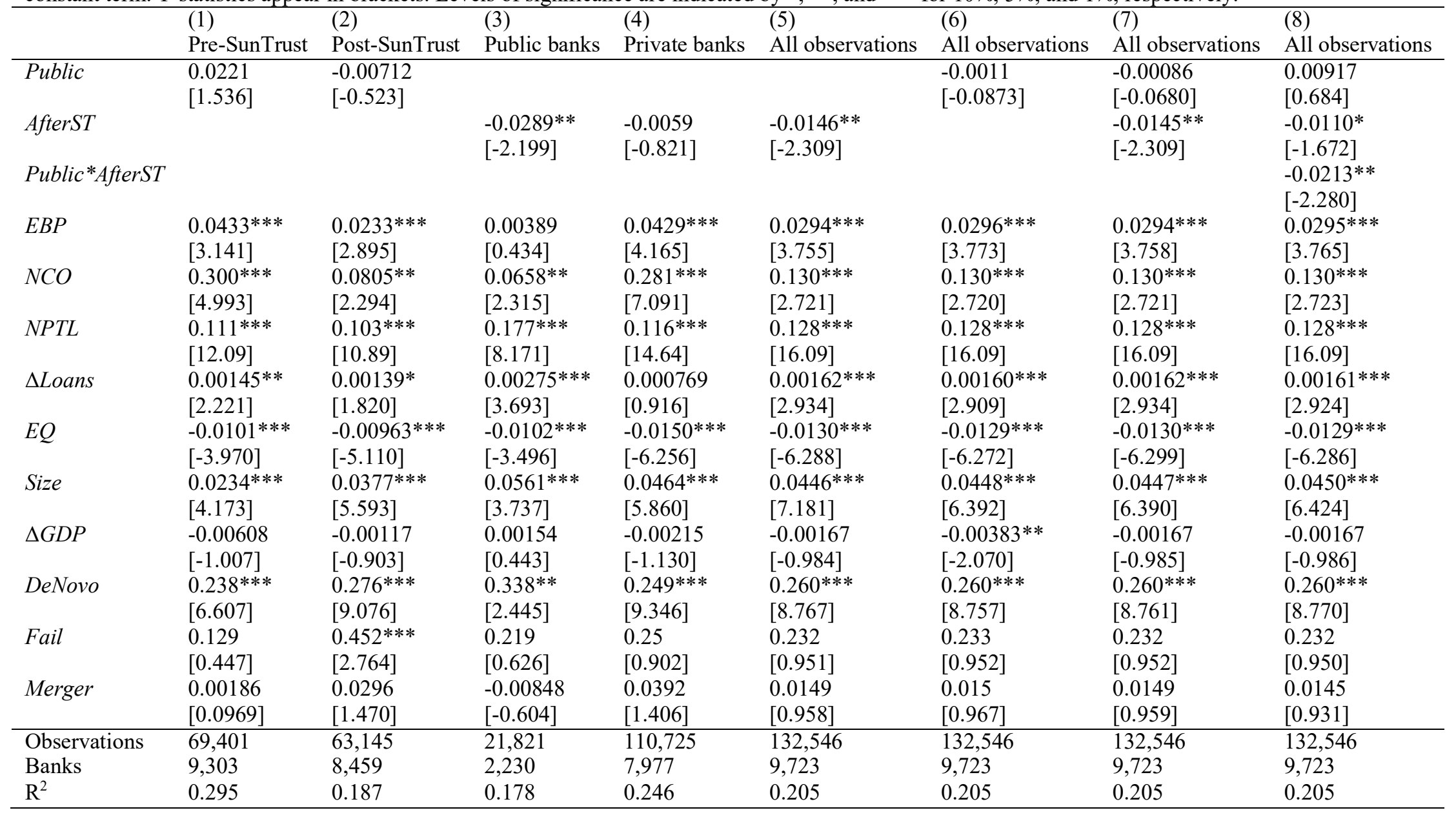


Table 7

Panel regressions of provisions for loan losses (PLL) using the full sample period. The sample periods for models 1 and 2 are 1992Q1-1998Q3 and 1999Q12007Q2, respectively. The sample period for models 3-8 is 1992Q1-2007Q2, with 1998Q4 (the quarter in which the SunTrust decision occurred) excluded.

Variables are as defined in Table 1. Specifications include random effects by bank, robust standard errors, quarter dummies, quadratic time trend variables, and a constant term. T-statistics appear in brackets. Levels of significance are indicated by *, **, and *** for $10 \%, 5 \%$, and $1 \%$, respectively.

\begin{tabular}{|c|c|c|c|c|c|c|c|c|}
\hline & $\begin{array}{l}\text { (1) } \\
\text { Pre-SunTrust }\end{array}$ & $\begin{array}{l}(2) \\
\text { Post-SunTrust }\end{array}$ & $\begin{array}{l}\text { (3) } \\
\text { Public banks }\end{array}$ & $\begin{array}{l}(4) \\
\text { Private banks }\end{array}$ & $\begin{array}{l}\text { (5) } \\
\text { All observations }\end{array}$ & $\begin{array}{l}\text { (6) } \\
\text { All observations }\end{array}$ & $\begin{array}{l}\text { (7) } \\
\text { All observations }\end{array}$ & $\begin{array}{l}\text { (8) } \\
\text { All observations }\end{array}$ \\
\hline \multirow[t]{2}{*}{ Public } & 0.0257 & -0.00537 & & & $0.0329^{*}$ & -0.00174 & $0.0318^{*}$ & 0.044 \\
\hline & {$[0.982]$} & {$[-0.266]$} & & & {$[1.885]$} & {$[-0.192]$} & {$[1.756]$} & [1.594] \\
\hline \multirow[t]{2}{*}{ AfterST } & & & $0.107 * * *$ & $0.0827 * * *$ & $0.0539 * * *$ & $0.0927 * * *$ & $0.0940 * * *$ & $0.0993 * * *$ \\
\hline & & & {$[3.070]$} & {$[4.659]$} & {$[11.47]$} & {$[6.041]$} & {$[6.219]$} & {$[5.722]$} \\
\hline \multirow[t]{2}{*}{ Public*AfterST } & & & & & $-0.0480 * * *$ & $-0.0416^{* * *}$ & $-0.0411 * * *$ & $-0.0654^{*}$ \\
\hline & & & & & {$[-5.563]$} & {$[-4.891]$} & {$[-4.804]$} & {$[-1.936]$} \\
\hline \multirow[t]{2}{*}{$E B P$} & $0.0392 * * *$ & $0.0371 * * *$ & $0.0348 * * *$ & $0.0517 * * *$ & $0.0382 * * *$ & $0.0446 * * *$ & $0.0498 * * *$ & $0.0514 * * *$ \\
\hline & {$[5.533]$} & {$[6.021]$} & {$[2.706]$} & {$[6.720]$} & {$[7.821]$} & {$[6.710]$} & {$[7.211]$} & {$[6.802]$} \\
\hline \multirow[t]{2}{*}{ EBP* Public } & -0.014 & -0.00767 & & & $-0.0170 * *$ & & $-0.0183 * *$ & $-0.0241 *$ \\
\hline & {$[-1.135]$} & {$[-0.789]$} & & & {$[-2.143]$} & & {$[-2.195]$} & {$[-1.760]$} \\
\hline \multirow[t]{2}{*}{$E B P^{*}$ After ST } & & & -0.0152 & $-0.0235^{* *}$ & & $-0.0201 * *$ & $-0.0206^{* * *}$ & $-0.0234 * *$ \\
\hline & & & {$[-0.941]$} & {$[-2.549]$} & & {$[-2.536]$} & {$[-2.634]$} & {$[-2.561]$} \\
\hline \multirow[t]{2}{*}{ EBP* Public ${ }^{*}$ AfterST } & & & & & & & & 0.0114 \\
\hline & & & & & & & & {$[0.660]$} \\
\hline \multirow[t]{2}{*}{$\mathrm{NCO}$} & $0.165 * * *$ & $0.122 * * *$ & $0.0919 * * *$ & $0.221 * * *$ & $0.174 * * *$ & $0.175 * * *$ & $0.175 * * *$ & $0.175^{* * *}$ \\
\hline & {$[6.970]$} & {$[4.178]$} & {$[3.222]$} & [11.09] & {$[6.517]$} & {$[6.521]$} & {$[6.543]$} & {$[6.536]$} \\
\hline \multirow[t]{2}{*}{$N P T L$} & $0.119 * * *$ & $0.122 * * *$ & $0.195 * * *$ & $0.111 * * *$ & $0.124 * * *$ & $0.124 * * *$ & $0.124 * * *$ & $0.124 * * *$ \\
\hline & {$[24.45]$} & {$[26.02]$} & [17.19] & {$[30.62]$} & [31.56] & [31.49] & [31.53] & {$[31.52]$} \\
\hline \multirow[t]{2}{*}{$\Delta$ Loans } & $0.00184 * * *$ & $0.00220 * * *$ & $0.00194 * * *$ & $0.00200 * * *$ & $0.00235^{* * *}$ & $0.00216 * * *$ & $0.00227 * * *$ & $0.00228 * * *$ \\
\hline & {$[4.328]$} & {$[5.626]$} & {$[4.020]$} & [4.892] & {$[7.544]$} & [7.116] & [7.306] & [7.328] \\
\hline \multirow[t]{2}{*}{$E Q$} & $-0.0160 * * *$ & $-0.00939 * * *$ & $-0.00893 * * *$ & $-0.0150 * * *$ & $-0.0135 * * *$ & $-0.0131 * * *$ & $-0.0132 * * *$ & $-0.0132 * * *$ \\
\hline & {$[-8.765]$} & {$[-6.732]$} & {$[-3.857]$} & {$[-9.627]$} & {$[-10.13]$} & {$[-10.03]$} & {$[-10.11]$} & {$[-10.12]$} \\
\hline \multirow[t]{2}{*}{ Size } & $0.0491 * * *$ & $0.0389 * * *$ & $0.0538 * * *$ & $0.0679 * * *$ & $0.0544 * * *$ & $0.0559 * * *$ & $0.0556 * * *$ & $0.0556 * * *$ \\
\hline & {$[9.266]$} & {$[8.352]$} & {$[4.161]$} & {$[10.85]$} & {$[10.53]$} & {$[10.86]$} & {$[10.77]$} & {$[10.79]$} \\
\hline \multirow[t]{2}{*}{$\triangle G D P$} & $0.00411 * *$ & $-0.0105 * * *$ & $-0.00900 * * *$ & $-0.00623 * * *$ & $-0.00673 * * *$ & $-0.00659 * * *$ & $-0.00661 * * *$ & $-0.00659 * * *$ \\
\hline & [2.198] & {$[-7.251]$} & {$[-2.870]$} & {$[-4.779]$} & {$[-5.613]$} & {$[-5.473]$} & {$[-5.486]$} & {$[-5.481]$} \\
\hline \multirow[t]{2}{*}{ DeNovo } & $0.148 * * *$ & $0.162 * * *$ & $0.133 * * *$ & $0.186^{* * *}$ & $0.177 * * *$ & $0.175^{* * *}$ & $0.175 * * *$ & $0.175 * * *$ \\
\hline & [9.446] & [18.39] & {$[4.747]$} & {$[17.63]$} & [17.92] & [17.98] & [18.04] & {$[17.97]$} \\
\hline \multirow[t]{2}{*}{ Fail } & $0.351 * *$ & $0.402 * * *$ & 0.35 & $0.436^{* * *}$ & $0.432 * * *$ & $0.436 * * *$ & $0.440 * * *$ & $0.441 * * *$ \\
\hline & {$[2.274]$} & {$[3.083]$} & [1.391] & [3.585] & [3.810] & [3.838] & [3.888] & [3.897] \\
\hline \multirow[t]{2}{*}{ Merger } & 0.00954 & -0.0141 & -0.0154 & -0.0107 & -0.0103 & -0.0115 & -0.0107 & -0.0107 \\
\hline & {$[0.862]$} & {$[-1.164]$} & {$[-1.525]$} & {$[-0.830]$} & {$[-1.218]$} & {$[-1.357]$} & {$[-1.265]$} & {$[-1.265]$} \\
\hline Observations & 265,500 & 252,322 & 82,983 & 434,839 & 517,822 & 517,822 & 517,822 & 517,822 \\
\hline Banks & 11,927 & 9,441 & 3,865 & 10,989 & 13,317 & 13,317 & 13,317 & 13,317 \\
\hline $\mathrm{R}^{2}$ & 0.216 & 0.211 & 0.219 & 0.205 & 0.213 & 0.215 & 0.214 & 0.214 \\
\hline
\end{tabular}


Table 8

Panel regressions of provisions for loan losses (PLL) using a narrow sample period. The sample periods for models 1 and 2 are 1996Q4-1998Q3 and 1999Q12000Q4, respectively. The sample period for models 3-8 is 1996Q4-2000Q4, with 1998Q4 (the quarter in which the SunTrust decision occurred) excluded.

Variables are as defined in Table 1. Specifications include random effects by bank, robust standard errors, quarter dummies, quadratic time trend variables, and a constant term. T-statistics appear in brackets. Levels of significance are indicated by *, **, and *** for $10 \%, 5 \%$, and $1 \%$, respectively.

\begin{tabular}{|c|c|c|c|c|c|c|c|c|}
\hline & $\begin{array}{l}\text { (1) } \\
\text { Pre-SunTrust }\end{array}$ & $\begin{array}{l}(2) \\
\text { Post-SunTrust }\end{array}$ & $\begin{array}{l}\text { (3) } \\
\text { Public banks }\end{array}$ & $\begin{array}{l}\text { (4) } \\
\text { Private banks }\end{array}$ & $\begin{array}{l}\text { (5) } \\
\text { All observations }\end{array}$ & $\begin{array}{l}\text { (6) } \\
\text { All observations }\end{array}$ & $\begin{array}{l}\text { (7) } \\
\text { All observations }\end{array}$ & $\begin{array}{l}\text { (8) } \\
\text { All observations }\end{array}$ \\
\hline \multirow[t]{2}{*}{ Public } & 0.064 & 0.021 & & & $0.0825^{* * *}$ & 0.00665 & $0.0774 * *$ & 0.0657 \\
\hline & {$[1.182]$} & {$[0.690]$} & & & {$[2.665]$} & {$[0.495]$} & {$[2.453]$} & {$[1.373]$} \\
\hline \multirow[t]{2}{*}{ AfterST } & & & 0.029 & 0.0152 & -0.00851 & 0.019 & 0.019 & 0.0144 \\
\hline & & & {$[0.641]$} & {$[0.607]$} & {$[-1.272]$} & {$[0.880]$} & {$[0.908]$} & {$[0.577]$} \\
\hline \multirow{2}{*}{ Public*AfterST } & & & & & $-0.0237 * *$ & -0.0151 & $-0.0179 *$ & 0.00195 \\
\hline & & & & & {$[-2.571]$} & [-1.549] & [-1.853] & {$[0.0418]$} \\
\hline \multirow[t]{2}{*}{$E B P$} & $0.0493 * * *$ & $0.0287 * *$ & 0.0196 & $0.0488 * * *$ & $0.0418 * * *$ & $0.0382 * * *$ & $0.0493 * * *$ & $0.0481 * * *$ \\
\hline & {$[2.859]$} & {$[2.490]$} & {$[1.031]$} & {$[3.428]$} & {$[4.026]$} & [3.317] & {$[3.771]$} & {$[3.414]$} \\
\hline \multirow[t]{2}{*}{ EBP* Public } & -0.0201 & -0.0137 & & & $-0.0353 * * *$ & & $-0.0340 * *$ & -0.0287 \\
\hline & {$[-0.822]$} & {$[-0.943]$} & & & {$[-2.660]$} & & {$[-2.484]$} & {$[-1.314]$} \\
\hline \multirow[t]{2}{*}{$E B P^{*}$ AfterST } & & & -0.0243 & -0.0111 & & -0.0157 & -0.0145 & -0.012 \\
\hline & & & {$[-1.262]$} & {$[-0.878]$} & & {$[-1.464]$} & {$[-1.392]$} & {$[-0.942]$} \\
\hline EBP* Public*AfterST & & & & & & & & -0.009 \\
\hline \multirow[t]{2}{*}{$\mathrm{NCO}$} & $0.302 * * *$ & $0.0817^{* *}$ & $0.0657^{* *}$ & $0.283 * * *$ & $0.133 * * *$ & $0.131 * * *$ & $0.133 * * *$ & $0.134 * * *$ \\
\hline & {$[5.020]$} & {$[2.298]$} & {$[2.336]$} & {$[7.078]$} & [2.759] & {$[2.736]$} & {$[2.770]$} & [2.773] \\
\hline \multirow[t]{2}{*}{$N P T L$} & $0.112 * * *$ & $0.103 * * *$ & $0.177 * * *$ & $0.117 * * *$ & $0.128 * * *$ & $0.128 * * *$ & $0.128 * * *$ & $0.128 * * *$ \\
\hline & [12.12] & [10.92] & [8.268] & {$[14.66]$} & {$[16.15]$} & {$[16.12]$} & {$[16.18]$} & {$[16.17]$} \\
\hline \multirow[t]{2}{*}{$\Delta$ Loans } & $0.00160 * *$ & $0.00147 *$ & $0.00249 * * *$ & 0.000772 & $0.00182 * * *$ & $0.00156^{* * *}$ & $0.00176^{* * *}$ & $0.00174 * * *$ \\
\hline & {$[2.213]$} & [1.895] & [3.143] & {$[0.922]$} & [3.153] & [2.814] & [3.029] & {$[2.978]$} \\
\hline \multirow[t]{2}{*}{$E Q$} & $-0.0104 * * *$ & $-0.00984 * * *$ & $-0.00905 * * *$ & $-0.0149 * * *$ & $-0.0132 * * *$ & $-0.0127 * * *$ & $-0.0130 * * *$ & $-0.0129 * * *$ \\
\hline & {$[-3.929]$} & {$[-5.097]$} & {$[-3.103]$} & {$[-6.196]$} & {$[-6.370]$} & {$[-6.144]$} & {$[-6.225]$} & {$[-6.210]$} \\
\hline \multirow[t]{2}{*}{ Size } & $0.0234 * * *$ & $0.0371 * * *$ & $0.0560 * * *$ & $0.0460 * * *$ & $0.0444 * * *$ & $0.0449 * * *$ & $0.0443 * * *$ & $0.0442 * * *$ \\
\hline & {$[4.215]$} & {$[5.533]$} & [3.758] & [5.881] & [6.329] & [6.443] & {$[6.351]$} & [6.347] \\
\hline \multirow[t]{2}{*}{$\triangle G D P$} & -0.00596 & -0.00116 & 0.00196 & -0.00196 & -0.00195 & -0.00142 & -0.00171 & -0.00173 \\
\hline & {$[-0.987]$} & {$[-0.901]$} & {$[0.552]$} & {$[-1.013]$} & {$[-1.146]$} & {$[-0.822]$} & {$[-0.985]$} & {$[-0.995]$} \\
\hline \multirow[t]{2}{*}{ DeNovo } & $0.238 * * *$ & $0.276^{* * *}$ & $0.332 * *$ & $0.246 * * *$ & $0.260 * * *$ & $0.256 * * *$ & $0.256 * * *$ & $0.257 * * *$ \\
\hline & {$[6.628]$} & {$[9.121]$} & {$[2.436]$} & {$[9.727]$} & {$[8.865]$} & [8.949] & [9.033] & [9.109] \\
\hline \multirow[t]{2}{*}{ Fail } & 0.124 & $0.458 * * *$ & 0.22 & 0.242 & 0.239 & 0.222 & 0.229 & 0.232 \\
\hline & {$[0.428]$} & {$[2.812]$} & {$[0.621]$} & {$[0.877]$} & {$[0.976]$} & [0.909] & {$[0.938]$} & {$[0.950]$} \\
\hline \multirow{2}{*}{ Merger } & 0.00281 & 0.0297 & -0.00925 & 0.0383 & 0.0153 & 0.0139 & 0.0147 & 0.0146 \\
\hline & {$[0.149]$} & {$[1.456]$} & {$[-0.647]$} & [1.384] & {$[0.975]$} & [0.901] & [0.945] & {$[0.932]$} \\
\hline Observations & 69,401 & 63,145 & 21,821 & 110,725 & 132,546 & 132,546 & 132,546 & 132,546 \\
\hline Banks & 9,303 & 8,459 & 2,230 & 7,977 & 9,723 & 9,723 & 9,723 & 9,723 \\
\hline $\mathrm{R}^{2}$ & 0.296 & 0.187 & 0.184 & 0.248 & 0.204 & 0.206 & 0.206 & 0.206 \\
\hline
\end{tabular}

